Article

\title{
Evaluating the Greenhouse Gas Emissions in the Craft Beer Industry: An Assessment of Challenges and Benefits of Greenhouse Gas Accounting
}

\author{
Rachel Shin ${ }^{1, *}$ and Cory Searcy ${ }^{2}$ \\ 1 Environmental Applied Science and Management Program, Ryerson University, \\ Toronto, ON M5B 2K3, Canada \\ 2 Department of Mechanical and Industrial Engineering, Ryerson University, \\ Toronto, ON M5B 2K3, Canada; cory.searcy@ryerson.ca \\ * Correspondence: rachel.shin@ryerson.ca
}

Received: 22 October 2018; Accepted: 11 November 2018; Published: 14 November 2018

\begin{abstract}
A growing number of companies in the brewery industry have made commitments to measure and reduce their greenhouse gas (GHG) emissions. However, many brewers, particularly craft brewers with relatively low rates of production, have not made such commitments. The purpose of this research was to investigate the challenges and benefits of measuring and reducing GHG emissions in the craft brewery industry. The research was conducted in Ontario, Canada, which has seen strong recent growth in the craft brewery industry. A case study and semi-structured interviews among Ontario Craft Brewers were conducted. The case study found that indirect (scope 3 GHGs under the WBCSD \& WRI GHG Protocol) GHG sources accounted for $46.4 \%$ of total GHGs, with major sources from barley agriculture, malted barley transportation, and bottle production. Direct emissions (scope 1) accounted for only 14.9\% of GHGs, while scope 2 emissions, comprised mainly of energy consumption, accounted for $38.7 \%$ of GHGs. The case study used case company primary data, and secondary data such as emission factors from external sources. The case study and interviews found that the main challenges in calculating brewery GHGs are secondary data availability, technical knowledge, and finances. The semi-structured interviews, which used prepared interview questions and probes to encourage follow-up answers, also found that the main benefits for Ontario breweries to measure their GHGs include sustainability marketing and preserving the environment. The interviews also found a poor understanding of carbon regulation among Ontario Craft Brewers, which is interesting considering that Ontario implemented a provincial cap and trade program in 2017.
\end{abstract}

Keywords: craft brewery; greenhouse gas accounting; carbon regulation; carbon footprint; cap and trade; institutional theory

\section{Introduction}

Beer is the fifth most-consumed beverage in the world [1]. In 2016, 1.96 billion hectoliters (hL) of beer was produced globally and beer now accounts for over three-quarters of global alcohol consumption [2,3]. The large scale of beer production has resulted in substantial environmental impacts due to intensive resource use. For example, it is estimated that alcoholic beverages, including beer, account for $0.7 \%$ of global greenhouse gas (GHG) emissions when the complete product lifecycle is considered $[4,5]$.

These GHG emissions arise primarily due to the intensive use of the agricultural materials, water, energy, and packaging materials needed to produce beer $[1,6,7]$. For example, a study found that 
1 litre $(\mathrm{L})$ of beer requires 0.269 kilogram $(\mathrm{kg})$ of malted barley, which is the main agricultural input for beer production [6]. Barley is a significant source of GHG emissions [6], with another study estimating that $0.57 \mathrm{~kg}$ of carbon dioxide equivalents $\left(\mathrm{CO}_{2} \mathrm{e}\right)$ are produced during the cultivation of $1 \mathrm{~kg}$ of barley [8]. Beer's packaging also constitutes a large source of GHG emissions, with estimates that it accounts for as much as $85 \%$ of the required energy across beer's lifecycle [9].

The GHG emissions attributed to brewing contribute to global climate change, but there is also a growing recognition that brewers are being impacted by changing climatic conditions. Studies have shown that the quality and supply of beer's raw material inputs, such as hops, is being threatened by climate change [10]. Hops are a sensitive crop impacted by changes to its growing season [10]. One study projects that hop yield in the Czech Republic, a global supplier of hops, will decrease by 7-9\% between 2026 and 2050 [10]. In 2014, water scarcity and temperature fluctuations significantly reduced the quantity and quality of barley in Canada, showing the major impacts climate change has on agricultural systems [11].

Beverage companies around the world have begun to measure, and attempt to reduce, the GHGs attributable to their operations. For example, a survey of global breweries revealed energy and water use intensity improvements between 2011 to 2015 [12]. The Beverage Industry Environmental Roundtable (BIER) formed a joint commitment on climate change in 2015, with 19 large commercial companies (including MolsonCoors, Denver, CO, USA and Montreal, QUE, CAN, Heineken, Amsterdam, The Netherlands, MillerCoors, Chicago, IL, USA and SAB Miller, London, UK) pledging to reduce energy consumption, invest in cleaner fuels, work with partners for increased climate change resiliency in agriculture, and reducing water usage [13]. The international shift in mandatory and voluntary action towards climate change mitigation among beer producers sets the precedence for research on the challenges and benefits of measuring and reducing GHG emissions for both small (craft) and large (commercial) breweries.

For the purposes of this paper, craft breweries are defined as those that produce $400,000 \mathrm{hL}$ or less of beer per year and that are independently owned [14,15]. Greater attention is needed on these producers given the rapidly growing consumption of craft beer globally, particularly among younger populations with high expendable income [3]. The major driving factors for craft beer consumption have been investigated, and include flavour, exposure to beer-related knowledge, and alternative choices to mainstream beer $[3,16]$. Industry research studies have completed carbon footprinting studies of beer, however these involved data from commercial breweries [17]. Given craft brewers' current growth, and anticipated growth going forward, it is important to investigate the extent to which craft breweries have accounted for their GHG emissions. As relatively small companies with limited resources, it is also important to investigate the benefits and challenges craft brewers face in measuring and reducing their GHG emissions, particularly within a provincial context with possible future costs from carbon regulation. Until a recently published study by Cimini \& Moresi, there was no research that applied the same methodology to compare the carbon footprints of small, medium, and large breweries in one study [18]. Previous to Cimini \& Moresi's study, studies calculated the carbon footprint of beer from a range of brewery sizes, and have primarily involved case studies in the United Kingdom, the USA, and Italy (among other European studies) [5,7,18-21]. A lack of Canadian-based research supports this study and its contribution to a geographically-specific case study. Moreover, previous research has shown that small firms generally disclose less on their environmental performance than their larger counterparts, suggesting results from studies of larger firms may not necessarily apply to small companies [22].

This paper explores the benefits and challenges of accounting for the GHG emissions of craft breweries in Ontario, Canada. Ontario was selected due to its rapid growth in craft breweries, the unique opportunity presented by its recent introduction of a cap and trade program, and the lack of GHG accounting and management research in this region. The paper specifically addresses two research questions: 
RQ1: What are the challenges of GHG accounting in craft breweries in Ontario?

RQ2: What are the benefits of GHG accounting in craft breweries in Ontario?

The questions were addressed through semi-structured interviews with representatives from 13 Ontario Craft Brewers and an in-depth case study with another Ontario Craft Brewer. The case study involved consultation with employees in the case company, collection of primary and secondary data, process mapping of the company's operations, and a scenario analysis of potential GHG emissions in the future. The globally-recognized GHG Protocol Accounting and Reporting Standard published by the World Business Council for Sustainable Development \& World Resources Institute was used to guide the GHG accounting in the case study [23]. Collectively, the case study and interviews found that the main challenges in calculating GHGs in craft breweries are data availability, technical knowledge, and finances. The benefits centered on sustainability marketing and preserving the environment. Notably, a poor understanding of Ontario's cap and trade carbon regulation was found. The paper introduces a structured approach to measure and analyze GHG emissions in a small company. As Cimini \& Moresi indicated, there is a need for carbon footprint studies in the beer industry to include traceable use of secondary data sources for replicability [18]. This paper also provides needed baseline information on the benefits and challenges of accounting for GHG emissions in craft brewers, which will provide evidence for where, and what, support is needed among craft brewers. Overall, this research is necessary in order to identify potential levers for change, as well as to identify the support and resources needed to advance GHG reduction efforts in the industry.

\section{Background}

\subsection{GHG Accounting in the Craft Brewery Industry}

The key inputs to beer production include raw materials, production, and packaging. The main raw material inputs are malted barley, water, hops and yeast [24]. The main resources used during production are electricity, gasoline and/or other transportation fuels, liquid carbon dioxide, and steam [24]. Packaging resources include glass, aluminum, paperboard, plastic, and steel [24]. Previous literature has noted the water- and energy-intensive nature of the brewing industry [1].

As craft breweries are becoming more popular, breweries' energy usage and associated GHGs have become a larger priority. For example, a case study reviewed the environmental impact mitigation actions of selected craft breweries in Virginia [25]. This case study found that reducing energy use and GHGs were prevalent actions taken among the case study craft breweries [25]. As another illustration of the growing environmental awareness in the industry, a survey of United States craft brewers found that small brewers recognize social and environmental sustainability as important, in part due to strong community engagement [26]. However, commercial brewers are more transparent in their environmental performance reporting as evidenced by published annual sustainability reports [26]. Commercial brewers, including Molson Coors and New Belgium Brewing, produce annual sustainability reports and have completed life cycle assessments, respectively [27,28].

There have been some efforts to account for brewery GHG emissions in the literature. Of particular focus here are studies that involved brewery inputs and outputs. Amienyo \& Azapagic produced a United Kingdom brewery company case study that calculated GHGs using process mapping, inventory data from the case company, global warming potentials of GHG emissions, and data approximations where direct measurements were not available along the value chain [21]. The key findings were that packaging comprised the majority of GHGs for beer production, with 50\% of GHGs for beer in glass bottles, and 35\% for steel cans [21]. Complementing the aforementioned study is Cimini \& Moresi's work on carbon footprint calculations of a lager packaged in kegs, aluminum cans, and glass bottles [5]. Cimini \& Moresi listed emission factors from their own calculations and from other sources for inputs and outputs such as glass, can, and keg packaging, recycling, hops, barley, and malted barley [5]. In Koroneos et al.'s life cycle assessment of beer at a case company based in Greece, steps along the value chain associated with major emissions were documented [9]. Specifically, it was found that the bottle 
production, brewing, and packaging phases of the value chain were the most emission-intensive [9]. Rajaniemi et al. focused their analysis on the GHGs from barley, oats, rye, and wheat [8]. They found that barley emits $570 \mathrm{~g} \mathrm{CO}_{2} \mathrm{e}$ per kg of barley produced [8]. Olajire assessed the life cycle of beer to identify major energy inputs and determined that the mashing and wort boiling stages are the most energy-intensive stages in the brewing process [1]. Finally, Muster-Slawitsch et al. created a process mapping structure for breweries to identify key GHG emission sources [29]. Several authors have noted that calculations vary depending on the geographical location, techniques employed, and technology used.

Efforts to reduce GHG emissions in the brewery industry have also been explored outside of the academic literature. For example, beyond generally-applicable guidelines, such as the GHG Protocol, some guidance for GHG measurement and reporting in the brewery industry is available. The Beverage Industry Environmental Roundtable (BIER), an organization comprised of globally-leading beverage producers, helps facilitate discussion, conduct research, and share best practice, particularly with regards to minimizing environmental impact [30]. For example, BIER produced an emissions calculation guide known as the "Beverage Industry Sector Guidance for Greenhouse Gas Emissions Reporting (Version 3)" [31]. Furthermore, BIER's "Research on the Carbon Footprint of Beer" provides an example of how to execute a carbon footprint analysis using process mapping and data collection [17]. Other insight into how craft brewers can measure their GHG emissions is available in a limited number of consultancy or non-governmental organization reports. For example, The Climate Conservancy published a report that was completed for New Belgium Brewery's Fat Tire Amber Ale [32].

\subsection{GHG Reduction Efforts and Craft Brewing in Ontario, Canada}

Carbon taxes and cap and trade are widely used today to regulate carbon emissions [33,34]. Cap and trade puts a limit on emissions (i.e., the cap), and a regulatory body allocates emission credits to participating companies [35]. A carbon tax puts a cost on each tonne of $\mathrm{CO}_{2}$ emitted, which may increase in price in subsequent years [34]. Ontario's cap and trade program, enacted in 2017, set a legal precedence for industries emitting more than 25,000 tonnes $\mathrm{CO}_{2} \mathrm{e}$ /year to participate by tracking and reporting their annual operational emissions [36]. These companies were issued a number of carbon credits, adjusted to their baseline emissions, where each credit represents one tonne of $\mathrm{CO}_{2} \mathrm{e}$ emissions [36]. Beyond the 25,000 tonne per year cap, qualifying companies were required to stay within their allocated carbon allowances, or purchase additional credits at quarterly-annual auctions [36]. Companies were also able to voluntarily participate in the cap and trade program if they exceeded 10,000 tonnes $\mathrm{CO}_{2}$ e/year [36].

Ontario's provincial government recently passed the Cap and Trade Cancellation Act, meaning Ontario no longer participates in a cap and trade system [37]. The Canadian federal government will require Ontario to legislate carbon pricing in the Spring of 2018, however, under their federal carbon pricing system [37]. Although Ontario's carbon regulation future is unknown, its cap and trade program presented a unique case study opportunity to investigate the perceptions and impacts of the program from a small-medium sized enterprise (SME), and specifically craft brewery, perspective.

Ontario has experienced rapid growth of craft breweries. In the 1980s, craft brewing in Ontario began to gain momentum [14]. In 2003, the Ontario Craft Brewer's Association (OCBA) was formed in an effort to show the quality and local community benefits of craft beer [14]. As of April 2018, the OCBA had 85 members [38], which sold 608,000 hL of beer in 2017 [14]. The industry's sales were $\$ 300$ million in 2017 [14]. In 2017, craft breweries captured 7.60\% of provincial beer sales in Ontario [14]. The industry employed 2250 full-time employees in 2017 [14,39].

Currently, there is little public data on OCBs' GHG emissions, nor much publicly-accessible information on carbon reduction programs and strategies. More specifically, there are no publicly-available carbon footprint studies of small breweries in Ontario. Through an analysis of 85 member companies of the 
OCBA, only 16 companies made any reference to environmental sustainability on their websites, with most not including any management plans or measurement variables. The low engagement among Ontario Craft Brewers in sustainability initiatives may be linked with low stakeholder expectations, and the practice of reporting on sustainability performance may be informed through institutional theory from cognitive, mimetic and normative pressures [40].

\subsection{Theory}

The two research questions addressed in this paper focus on the benefits and challenges of GHG accounting among OCBs. The literature indicates that craft brewers have taken relatively little action towards measuring and reducing their GHG emissions. This suggests that many craft brewers either perceive that the challenges outweigh the benefits or that they are unable to take the actions necessary to overcome those challenges and obtain the benefits. Insight into the potential benefits and challenges of reducing GHG emissions may be provided through the lens of institutional theory and image theory.

\subsubsection{Institutional Theory}

Institutional theory states that a businesses' environment shapes its actions and behaviours, and that over time, businesses within the same industry will behave similarly as a result of their exposure to the same environmental pressures [41,42]. Three isomorphic pressures have relevance to craft brewery GHG emission reduction: coercive, mimetic, and normative.

Coercive pressure is constraining because it can be externally enforced on companies through laws and sanctions [41,43]. For example, Ontario's cap and trade program was a method of carbon regulation that compelled companies to measure and, ideally, reduce their GHG emissions. As a result of the program, qualifying companies were required to take similar actions to measure, document, and publicly report their GHG emissions. However, Ontario craft brewers were exempt from the mandatory requirements in the program, since their emissions were less than the 25,000 tonne per year cap. Although the pressure exerted by the cap and trade program on Ontario craft brewers was therefore weak, they may have been impacted by supplier cost increases.

Normative pressure is behaviourally-influenced from commonly-held values and actions which can be developed through academic and professional backgrounds [41]. Normative pressure may be the largest impact of the three pressures for breweries, as their company morals and behaviours are influenced by employees, peers, suppliers, and consumers. Normative pressure may influence institutional practices regarding carbon management whereby actors perpetuate the impacts of climate change and connection of the Ontario craft brewing industry to global warming. Normative pressure is perhaps more influential among smaller organizations, such as OCBs, because they have smaller networks, and arguably less hierarchy within companies where each employee can have a larger impact. These pressures, however, are likely to be moderate, since, like in other small companies, environmental management is likely to have a relatively low profile within craft brewers. Craft brewers, for example, are unlikely to employ full-time personnel focused on environmental management.

Mimetic (cognitive) pressure influences similar companies with similar goals and communities to emulate one another as a way of benchmarking their own success [41,43]. For example, if one OCB begins to manage their carbon emissions, similar companies may do the same if they see it is financially beneficial. Mimetic pressure is beneficial to businesses as it can reduce uncertainty, since mimicking similar companies will (likely) yield similar outcomes [43]. However, the review of literature for this study indicates that there are few high-profile and relevant examples (in terms of geography, size, and technology) for craft breweries to mimic at the time of this study. Mimetic pressures for GHG reduction in the craft brewery industry, therefore, are likely to be weak.

Based on the above review of the literature, craft brewers in Ontario are likely subject to weak coercive and mimetic pressures, and moderate normative pressures. Institutional theory may, therefore, help explain the relative lack of investment in GHG emission reduction that are not perceived to have a high positive return on investment and the slow pace of adoption of GHG management plans and 
technologies. Institutional theory indicates that Ontario craft brewers are likely to cite challenges to GHG measurement and reduction such as a lack of limited finances due to other external taxes (coercive pressure), and best practices to model (mimetic pressure).

\subsubsection{Image Theory}

Image theory reflects the operational and managerial choices adopted by decision-makers based on the present and future vision these decision-makers have for the company [42]. Decision-makers continually evaluate their choices in the context of their business image for the company to make sure there are no inconsistencies [41]. Image theory would explain that two decision-makers, faced with the same decision, may conclude different actions are most appropriate for their business based on images formed by different values [44]. An important aspect of image theory is that while decision-makers form a course of action alone, it may be influenced and changed by group (i.e., corporate) dynamics [44].

According to image theory, there are three images which are used by the decision maker to organize the decision-making process: value image, trajectory image, and strategic image [44]. Value image involves the moral soundness of prospective actions as deemed by the decision-maker [44]. Trajectory image reflects the decision-makers' pre-conceived (abstract or measureable) goals regarding future achievements and directions [44]. Finally, the strategic image is made of plans or steps used in achieving the trajectory image, and is used to evaluate the progress towards achieving the trajectory image (i.e., the goal) [44]. Value, trajectory, and strategic images are used to reject or screen for choices that do not align with the decision maker. After this screening exercise, a consideration of the costs and benefits of the acceptable options informs the adopted choice [44,45].

Image theory may have a notable impact in the decision-making process of craft breweries because of the relatively few decision-makers in Ontario craft breweries (as compared to larger corporations) and thus the increased ability for craft brewery staff values to influence leadership values and decisions. Furthermore, image theory is relevant in the decision-making process of craft breweries given the subjective consideration of values, the current and future environment within which the business operated, and the reiterative evaluation of decisions. For example, following craft brewery implementation of a program, evaluation may be ongoing to determine the financial, environmental, or other intended impact of the program. Applying image theory may also clarify why branding images, and the actions that support a branding image, are varied between craft breweries of comparable sizes and products. In line with this, image theory may help in understanding what (i.e., cost savings or environmental health) influences OCBs' investment decisions to reduce GHG emissions.

Given this study's research questions (i.e., RQ1 and RQ2) and image theory's framework, the perceived challenges and benefits among craft brewers are expected to vary due to different company images. Image theory may help explain why brewers have different perceptions of costs versus benefits associated with carbon accounting and management.

\section{Materials and Methods}

Two phases were employed to address the two research questions: (1) interviews with representatives from OCBs, and (2) a case study with another $\mathrm{OCB}$, consisting of process mapping, GHG calculations, and a scenario analysis. Both phases focused on addressing both research questions. The interviews provided an opportunity to study the challenges and benefits of GHG accounting in OCBs at a high-level with a number of different companies. The case study complemented those findings by providing an opportunity to study those challenges and benefits in much greater depth and detail. 


\subsection{Ontario Craft Brewer Interviews}

Representatives from 82 of the 85 companies registered (as of April 2018) with the OCBA [38] were invited to participate in the interviews. The study protocol was approved by the Human Research Ethics Board Committee at Ryerson University, Toronto, ON.

The company used for the in-depth case study was one of the three companies excluded from interviewee recruitment; contact information for the other two breweries were unavailable. The invitations, sent by email, were targeted to sustainability managers, or equivalent, positions within each company. In companies where such positions did not exist, the interviews targeted senior managers who would be aware of the company's GHG measurement and reduction initiatives (if any). Follow-up emails were sent one and two weeks following the initial contact to non-respondents. Representatives from 13 different companies ultimately participated in the research of the 82 that were invited to participate, equating to a response rate of $16 \%$.

The interviews used semi-structured, exploratory interview techniques to shape a dialogue of OCBs' perceptions of the challenges and benefits of GHG accounting. Other questions focused on providing additional context, including details on the companies' ongoing efforts to measure and reduce their GHG emissions and their perspectives on provincial carbon regulation. The interviews were recorded and transcribed. All participants were provided with the opportunity to make revisions to their transcript if they wished. All participants were also promised that their comments would remain confidential. See Appendix A, Table A1 for a complete list of interview questions.

The transcripts were manually reviewed and coded using a general inductive approach [46]. The interviews were read and re-read as part of an iterative coding process. Codes were mainly developed a posteriori for the interview analysis. From a content analysis of websites of OCBA members prior to the interviews, sustainability code words were identified (see Appendix B, Table A2). These code words preluded what was expected from the interview findings, however, interview codes were developed after reading the transcripts, and iteratively modified during the interview analysis. An intra-rater reliability test of the interview analysis was conducted, with a Krippendorf's Alpha of 0.925 , indicating a high level of agreement [47].

\subsection{Ontario Craft Brewer Case Study}

The case company is a craft brewery located in Ontario, and is independently owned and operated. The case company is a mid-sized company that employed less than 250 full- or part-time employees in 2016, which is the year from which data was used for the case study. In 2016, the case company produced less than 100,000 hL of beer. The case company's age was less than 20 years old as of 2016 . The case company was promised confidentiality.

The researchers collected primary data from the case company, mapped their operations, collected primary and secondary data, and calculated the company's 2016 annual GHG emissions, and future projections of annual GHGs, by using the globally-recognized GHG Protocol Accounting and Reporting Standard. Table 1 summarizes the GHG accounting methodology used in the case study. Table 1 shows a chronological list of actions taken to complete the GHG accounting for the case study, including setting operational boundaries, collecting data, and documenting calculations. Note that Scope 1, 2, and 3 emissions, as defined under the GHG Protocol, were included in the study. Scope 1 emissions are directly emitted by the company of interest (i.e., fleet fuel usage), scope 2 emissions are generated through purchased utilities (i.e., electricity, steam, heating and cooling), and scope 3 emissions are generated through all other processes that occur upstream and downstream from the company of interest (i.e., fuel usage from supplier vehicles, and GHGs associated with beer packaging) [48]. 
Table 1. Greenhouse gas accounting and reporting standards applied to the case company. Standards include the GHG Protocol Accounting and Reporting Standard (referred to as ARS in the Table) [23], GHG Scope 3 Accounting and Reporting Standard (referred to as ARS3 in the Table) [48], and the BIER Reporting Standard [31]. The case company is referred to as Company A in the Table.

\begin{tabular}{|c|c|}
\hline Step Description & $\begin{array}{l}\text { Standards and Supplementary } \\
\text { Materials Referenced }\end{array}$ \\
\hline \multicolumn{2}{|l|}{ Greenhouse gas accounting } \\
\hline $\begin{array}{l}\text { Meet with Company A to determine why they are interested in } \\
\text { calculating their carbon footprint; what are their goals and intended } \\
\text { use of this information. }\end{array}$ & Chapter 2 GHG Protocol ARS [23] \\
\hline $\begin{array}{l}\text { Set organizational and operational boundaries. Since Company A is } \\
\text { independently owned and operated, its direct and indirect processes } \\
\text { are included in the analysis. Operational boundaries determine } \\
\text { whether direct (scope } 1 \text { and 2) or indirect emissions (scope } 3 \text { ) are to } \\
\text { be included in calculations. Under the GHG Protocol, it is } \\
\text { mandatory to account for scope } 1 \text { and } 2 \text { emissions, while scope } 3 \\
\text { emissions are voluntary. Scope } 3 \text { emissions are recommended for } \\
\text { inclusion when they are significant in magnitude, have future risk } \\
\text { associated, and/or face sociopolitical instability (source i. and ii.). }\end{array}$ & $\begin{array}{l}\text { i. Chapter } 3 \text { and } 4 \text { GHG Protocol } \\
\text { ARS [23] }\end{array}$ \\
\hline $\begin{array}{l}\text { Since Company A is independently owned, the control approach as } \\
\text { outlined in the GHG Protocol ARS3 is used, so all calculated GHGs } \\
\text { are applied to Company A. For companies that have split ownership, } \\
\text { use the equity approach to greenhouse gas accounting, where } \\
\text { emissions are calculated and reported relative to ownership } \\
\text { structure (source ii.). }\end{array}$ & $\begin{array}{l}\text { ii. Chapter } 3 \text { GHG Protocol ARS3, } \\
\text { [48] }\end{array}$ \\
\hline
\end{tabular}

Set a baseline from which to calculate greenhouse gas emissions. The greenhouse gas emissions in the baseline year will be used to inform reduction goals for the future. Data from 2016 is used for Chapter 5 GHG Protocol ARS [23] Company A.

Collect primary data (provided by Company A) and identify as scope 1, 2 or 3 . Use a centralized approach (primary data collected from Company A's corporate office). Collect secondary data as required (i.e., emission factors) from external sources. Scope 3 emission data collection should be prioritized by its magnitude relative to other scope 3 emission sources (source i.).

\begin{tabular}{|c|c|}
\hline $\begin{array}{l}\text { Calculation approaches should be documented and consistent; } \\
\text { purchase records (i.e., fuel, electricity, other raw materials) and } \\
\text { activity records (i.e., kilometers travelled) are appropriate sources of } \\
\text { Company A data (source ii.). }\end{array}$ & $\begin{array}{l}\text { ii. Chapter } 7 \text { GHG Protocol ARS3 } \\
\text { [48] }\end{array}$ \\
\hline $\begin{array}{l}\text { Carbon dioxide, methane, nitrous oxide, hydrofluorocarbons, } \\
\text { perfluorocarbons, and sulfur hexafluoride are the six GHGs } \\
\text { included in calculations of scope } 1,2 \text {, and } 3 \text { emissions (source iii.). }\end{array}$ & $\begin{array}{l}\text { iii. Glossary GHG Protocol ARS } \\
\text { [23] }\end{array}$ \\
\hline $\begin{array}{l}\text { Work with the primary contact at Company A to identify and collect } \\
\text { missing data appropriate for the GHG calculations. }\end{array}$ & $\begin{array}{l}\text { Supplier Engagement Guidance } \\
\text { [49] }\end{array}$ \\
\hline $\begin{array}{l}\text { Calculate greenhouse gas emissions from primary and secondary } \\
\text { data. This is in line with the calculation method, with the alternative } \\
\text { being the direct measurement method. Decisions as to whether to } \\
\text { use primary or secondary data should be based on data availability } \\
\text { and goals of the GHG accounting (source i.). }\end{array}$ & $\begin{array}{l}\text { i. Emission-factors from cross } \\
\text { sector tools [50] }\end{array}$ \\
\hline Formula for calculation method (source ii): & $\begin{array}{l}\text { ii. Chapter 6, } 7 \text { \& } 9 \text { GHG Protocol } \\
\text { ARS [23] }\end{array}$ \\
\hline $\begin{array}{l}\text { GHG }=\text { activity data } x \text { emission factor } x \text { greenhouse warming } \\
\text { potential }\left(\mathrm{GWP}_{100}\right)\end{array}$ & $\begin{array}{l}\text { iii. Chapter } 7 \text { GHG Protocol ARS3 } \\
\text { [48] }\end{array}$ \\
\hline
\end{tabular}

i. Chapter 6 GHG Protocol ARS [23] 
Table 1. Cont.

\begin{tabular}{|c|c|}
\hline Step Description & $\begin{array}{l}\text { Standards and Supplementary } \\
\text { Materials Referenced }\end{array}$ \\
\hline $\begin{array}{l}\text { Use sector-specific or cross-sector tools for GHG calculations. } \\
\text { The most recent greenhouse warming potentials (GWPs) produced } \\
\text { by the International Panel on Climate Change (IPCC) should be } \\
\text { used with a 100-year horizon (expressed as GWP100) for conversion } \\
\text { of all GHGs to carbon dioxide equivalents }\left(\mathrm{CO}_{2} \mathrm{e}\right) \text { (source iii.). }\end{array}$ & $\begin{array}{l}\text { iv. United Nations Framework } \\
\text { Convention on Climate Change } \\
\text { (UNFCCC) Canadian } 2017 \\
\text { submission [51] }\end{array}$ \\
\hline \multicolumn{2}{|l|}{$\begin{array}{l}\text { Maintain a clear record of data sources, assumptions, and } \\
\text { calculations used. These records can be used to verify GHG } \\
\text { calculations in an internal and/or external audit (source iv.). }\end{array}$} \\
\hline $\begin{array}{l}\text { Design the GHG database to allow Company A to add, modify, and } \\
\text { track emissions over time. }\end{array}$ & Chapter 3 GHG Protocol ARS [23] \\
\hline \multicolumn{2}{|l|}{ Greenhouse gas reporting } \\
\hline $\begin{array}{l}\text { When publicly reporting GHG emissions, absolute values must be } \\
\text { reported. Ratios can also be useful to report to compare performance } \\
\text { over time. Common ratios to report include efficiency (unit GHG } \\
\text { produced per volume of beer), productivity (GHG produced per } \\
\text { dollar revenue), and percentage ratios to compare performance } \\
\text { over years. }\end{array}$ & Chapter 9 GHG Protocol ARS [23] \\
\hline \multicolumn{2}{|l|}{ Scenario analysis } \\
\hline $\begin{array}{l}\text { After reviewing the GHG calculations with Company A, } \\
\text { recommendations for scenario analysis will be made to see how } \\
\text { GHG amounts change due to internal and external changes. }\end{array}$ & [52-54] \\
\hline
\end{tabular}

The choice of primary data to include in the case company's GHG calculations was determined by two factors: (1) the scope of the case company GHG calculations; and (2) data availability. Based on consultations with the case company, emissions involved in beer production, packaging, and distribution were included, with the final output unit being identified as tonnes of carbon dioxide equivalents per year per hectolitre of beer produced ( $\mathrm{t} \mathrm{CO}_{2}$ eper year/hL beer). The second factor, data availability, also influenced what primary data was used for the GHG calculations. The case company provided the researchers with the data they collect on a per month and per year basis.

The choice of secondary data to include in the case company's GHG calculations was determined by the following factors: (1) reliability and breadth of data from each source; (2) geographic relevance; (3) technological relevance; and (4) temporal relevance. Secondary data included data that was not available directly through the brewery (i.e., suppliers' truck fuel efficiency, and global warming potential conversion factors used to convert different types of GHGs to units of $\mathrm{CO}_{2} \mathrm{e}$ ). The first factor, reliability and breadth of data from secondary data sources, refers to the reputation of the publisher of the secondary data. For example, data from the "2017 Canadian National Inventory Submission to the United Nation's Framework Convention on Climate Change" and the "2017 World Resources Institute (WRI) Emission Factors from Cross Sector Tools" were used for 23 of 59 secondary data values [50,51]. The WRI Emission Factors provided varying emission factors based on country (i.e., United States, United Kingdom, and other). The "other [country]" emission factor data from these sources was primarily used in this study, followed by United States data and United Kingdom data when needed. Although the WRI source did not specifically provide emission factor data for Canada, the source provided data for countries with comparable levels of technology. The Canadian National Inventory Submission fulfilled the reliability and breadth, geographic, and temporal relevance factors; whereas the WRI Emission Factors fulfilled the reliability and breadth, and temporal relevance factors. The data for the remaining 36 of 59 emission factors collected from secondary data sources were primarily from academic journal papers, corporate consultancy reports, the Intergovernmental Panel on Climate Change 2014 Synthesis Report, and databases such as BUWAL 250 and Ecoinvent. 
See Table A3 in Appendix $C$ for details. Given the nature of the limited primary data collected by the case company, and contextual differences in the secondary data collected for the GHG calculations, there is a moderate amount of uncertainty in this study's GHG calculations.

To prompt thinking and discussion about the benefits and challenges of GHG reduction over time, an internal operations scenario was analyzed using a 10-year time horizon. The volume of beer (measured in $\mathrm{hL}$ ) packaged in aluminum cans versus beer bottles per year was varied to test the change in $\mathrm{CO}_{2} \mathrm{e}$ emissions associated with beer packaging. This scenario analysis was applied to this research to determine whether cost savings could arise 10 years from now by changing present day operations, which could shift the perception of costs and benefits from the brewery's point of view. For example, if carbon accounting has a high cost relative to its financial benefits in year 1, in year 10 the carbon accounting price may be (relative to saved expenses) a low cost in year 10. For the packaging scenario, two dimensions were crossed to form matrices for evaluation (see Table 2). The scenario forecasted the case company's beer sales over a 10-year period (between 2018 and 2028) and combined this with an internal variable (i.e., volume of beer packaged in aluminum cans and glass bottles). This calculation thus forecasted the impact of beer packaging on total brewery GHG emissions given the projected sales growth.

Table 2. Scenario analysis matrix. The first variable, "Case company beer production (hL)" uses primary, intermediate, and advanced growth projections to estimate beer production in the year 2028. The second variable, "Change (in $\mathrm{hL}$ ) in beer packaged in bottles vs. cans" uses primary, intermediate, and advanced growth projections to estimate the increase in can packaging and decrease in bottle packaging in the year 2028.

\begin{tabular}{|c|c|c|c|c|}
\hline \multicolumn{5}{|c|}{$\begin{array}{c}\text { Scenario 1: 10-Year Horizon } \mathrm{CO}_{2} \text { e with Beer Production Estimates } x \text { Bottle Versus Can Production } \\
\text { Ratio }\end{array}$} \\
\hline & & \multicolumn{3}{|c|}{ Case Company Beer Production (hL) } \\
\hline & & $\begin{array}{l}\text { Primary } \\
\text { Scenario }\end{array}$ & $\begin{array}{l}\text { Intermediate } \\
\text { Scenario }\end{array}$ & $\begin{array}{l}\text { Advanced } \\
\text { Scenario }\end{array}$ \\
\hline \multirow{3}{*}{$\begin{array}{l}\text { Change (in } \mathrm{hL} \text { ) in } \\
\text { beer packaged in } \\
\text { bottles vs. cans }\end{array}$} & $\begin{array}{l}\text { Primary } \\
\text { Scenario }\end{array}$ & $\begin{array}{l}\mathrm{CO}_{2} \mathrm{e} \text { emissions } \\
\text { estimate \#1 }\end{array}$ & $\begin{array}{l}\mathrm{CO}_{2} \mathrm{e} \text { emissions } \\
\text { estimate \#2 }\end{array}$ & $\begin{array}{l}\mathrm{CO}_{2} \mathrm{e} \text { emissions } \\
\text { estimate \#3 }\end{array}$ \\
\hline & $\begin{array}{l}\text { Intermediate } \\
\text { Scenario }\end{array}$ & $\begin{array}{l}\mathrm{CO}_{2} \mathrm{e} \text { emissions } \\
\text { estimate \#4 }\end{array}$ & $\begin{array}{c}\mathrm{CO}_{2} \mathrm{e} \text { emissions } \\
\text { estimate } \# 5\end{array}$ & $\begin{array}{c}\mathrm{CO}_{2} \mathrm{e} \text { emissions } \\
\text { estimate } \# 6\end{array}$ \\
\hline & $\begin{array}{l}\text { Advanced } \\
\text { Scenario }\end{array}$ & $\begin{array}{c}\mathrm{CO}_{2} \mathrm{e} \text { emissions } \\
\text { estimate } \# 7\end{array}$ & $\begin{array}{c}\mathrm{CO}_{2} \mathrm{e} \text { emissions } \\
\text { estimate \#8 }\end{array}$ & $\begin{array}{c}\mathrm{CO}_{2} \mathrm{e} \text { emissions } \\
\text { estimate } \# 9\end{array}$ \\
\hline
\end{tabular}

The first dimension for the packaging scenario was calculated using a 2015-2017 growth percentage figure published by the Ontario Craft Brewer's Association [39]. Primary (i.e., actual), intermediate, and advanced percentage growth estimations were created from the baseline 2015-2017 annual growth percentage reported by the OCB. The baseline annual growth percentage in craft beer revenue reported by the OCB was used as the intermediate scenario (24\%), while the primary scenario was an $18 \%$ growth and the advanced scenario reflected a $30 \%$ growth.

The second dimension for the packaging scenario used 2015 and 2016 case company data to calculate the change of $\mathrm{hL}$ beer packaged in aluminum cans per year and $\mathrm{hL}$ beer packaged in glass bottles per year. The primary scenario did not change the percentage of beer packaged in cans and bottles, the intermediate scenario increased can packaging by $10 \%$ and decreased bottle packaging by $10 \%$, and the advanced scenario increased can packaging by $20 \%$ and decreased bottle packaging by $20 \%$. Growth of can versus bottle packaging was chosen based on evidence from Beer Canada, who reported that in 2012, the Canadian beer market was comprised of $44 \%$ bottled beer and $46 \%$ of canned beer (with 10\% in kegs), whereas in 2017, canned beer sales rose to $60 \%$ of the market [55]. 


\section{Results}

\subsection{Ontario Craft Brewer Interviews}

The purpose of the interviews was to investigate the key challenges and benefits of reducing GHG emissions in craft breweries. Eighty-two Ontario Craft Brewers were invited for an interview, and 13 interviews were conducted.

\subsubsection{Interviewee Background}

Thirteen of 82 invited OCBs participated in an interview, representing a response rate of $16 \%$. There was a great range in brewery age and production volume among the brewery interviewees. The newest brewery was established in 2017, while the oldest brewery was established in 1985. The median age was four years old (i.e., established in 2014). The production volume ranged from 287 $\mathrm{hL} /$ year (where $1 \mathrm{hL}=100 \mathrm{~L}$ ) to $67,000 \mathrm{hL} /$ year. The median production volume was 15,000 hL/year. Six of the 13 breweries that participated in the interviews had some environmental keywords appearing on their websites. The other 7 had no environmental keywords on their websites.

To provide some context for discussing the challenges and benefits of GHG reduction, the interview participants were also asked several background questions on the measurement of their electricity usage, their business priorities with respect to GHG emission reduction, and their thoughts on efforts to reduce GHG emissions as a whole in the craft brewer industry.

\subsubsection{Interview Results}

The interviews found that the most common barrier to measuring and reducing GHGs (as per RQ1) was financial cost $(n=7)$, followed by human resources $(n=4)$. The most common benefit to measuring and reducing GHGs (as per RQ2) was environmental sustainability marketing $(n=9)$, followed by a desire to preserve the natural environment $(n=4)$.

Seven interviewees explained that measuring their GHG emissions is a business priority for their brewery, though only 2 of the interview participants specifically measured their GHG emissions at the time of this study. The other 5 stated they are considering measuring their GHGs in the future. Ten of 13 interviewees have heard of, or know, what cap and trade is. Of those that shared their perspectives on cap and trade brewery impacts, two participants thought cap and trade will negatively impact their brewery, while three did not think it would impact their brewery. Eight of 13 participants thought that, overall, Ontario Craft Brewers as a whole are not doing enough in terms of their considerations and actions to reduce GHGs. One interviewee thought the industry is acting effectively to reduce GHGs, while another single interviewee stated the industry as a whole is at least broadly aware of their GHG emissions.

\subsubsection{Interview Challenges in GHG Measurement and Reduction}

The main barrier to GHG management identified from the interviews is financial cost $(n=7)$. The participants cited that competing priorities, such as a focus on growing production, and small marginal profits limited craft breweries in what they are able to dedicate to GHG management. For example, one company explained, "...at this point in our game we have to be very conscientious of where we spend our money" (Company P04). As the same participant further explained, the brewery's overriding focus was simply staying in business and that "it's very difficult to survive as a manufacturing operation in Ontario" (Company P04). The challenges of a small businesses essentially trying to survive, was echoed by others. For example, a participant from another company stated:

"We're still coming out of like trying to pay off a lot of expenses, the money is like super, super tight right now and we're still not operating like in the positive yet ... our business model has to ... have some sort of cost savings associated with it and to me that's a challenge..." (Company P06). 
Breweries who cited financial cost as a barrier indicated it was a large consideration in their GHG management decisions, or that it has been preventing them from measuring and reducing their GHGs. However, even some of the breweries citing financial concerns did indicate that they would be willing to invest in GHG management if their cash flow position would allow for it. For example:

" ... if we had a better cash flow we'd be willing to make some sacrifices to change the way that we do things, even if it was more costly but it's certainly an industry that has razor thin margins especially when you're starting" (Company P13).

While financial performance was a priority among all interviewees, there was great variation between companies in other business priorities. For example, one participant (Company P07) stated that profit maximization is not the singular and sole goal of the company, but rather that the brewery's goal includes producing sustainable beer and supporting the local community.

The second largest barrier to breweries' GHG management was human capital limitations $(n=4)$. Specifically, these interviewees found that limited staff, and staff hours, was a major barrier in devoting resources to GHG management:

"We have no time to collect data ... we continue to be a small staff but we're really focused on making and selling beer, that is our business ... I don't want my people involved. I'll do what I can, you know, but to me, like right now, knock on wood we're doing very well, but I need all hands on deck, you know, making beer ... as we get bigger and we have more roles to play, there might be an opportunity to have an ... environmental lead person in a brewery, may be in charge of our wastewater and in charge of our emissions and in charge of all environmental stuff, but we're a long way away from that right now" (Company P04).

In a related issue, the interviewees noted that they had difficulty accessing appropriate resources and that it would be helpful if additional support was available from the provincial government. As one participant explained:

"... maybe having groups or agencies that can sort of give a helping hand and educate on ways to reduce carbon emission and other sort of environmentally unfriendly things that happen at [brewery name], we are probably one of the bigger craft breweries, but there are many, many people that are smaller than us that would have even less resources than we do and honestly it's likely not a priority for a lot of businesses it's based on priorities and a lot of financial perspectives and the craft beer industry is struggling right now in general" (Company P10).

Other interviewees stated that knowledge sharing amongst craft breweries was not as strong as it could be. One participant noted that the Ontario Craft Brewers Association could take a greater role facilitating knowledge-sharing with respect to GHG management:

[In reference to OCB member meetings]: "I don't recall us actually talking about greenhouse gas emissions at the sessions, I mean there's lots on wastewater management and you know, quality assurance and those things, but not as much on greenhouse emissions ... " (Company P12).

One interviewee noted that they were interested in learning more about what other breweries were doing on GHG emissions reduction, another area where the OCBA might help promote knowledge sharing:

“... we don't necessarily see a lot of what initiatives are going on from what companies aren't publicly traded, like you know, there's not a lot of small brewers that are publishing their annual sustainability reports and so it's very hard for us to gauge and I think that you know, our industry is actually really good with sharing best practices around a lot of other things and it's still very collegial and I sense that that will also extend to sustainability and 
carbon management, but the fact that we haven't really heard about it to me indicates that our industry isn't there and so there's not much to share otherwise they would be more collaborative around that, in my mind." (Company P13).

A barrier to GHG accounting is that three of thirteen brewers interviewed were unaware of what cap and trade is and/or have not heard of cap and trade in Ontario. Of the ten participants that knew of cap and trade, three believed it would not have direct negative brewery impacts, two believed it would have direct negative brewery impacts, and one was not sure if cap and trade will have industry impacts. Four of ten participants did not comment. The mixed levels of awareness were potentially crucial barriers to GHG reduction because if cap and trade is not perceived as a potential future cost (i.e., through supply chain costs or directly due to the brewery's growth), the benefits of carbon reduction and management in the present to mitigate future costs is being omitted. This means that future benefits to carbon management may be undervalued relative to present day costs of implementing carbon management. Examples of the understanding of Ontario's cap and trade program on OCBs are:

"I'm assuming that we have to pay something for it in future and this will be like, it won't cripple us but it is a worry, an ongoing worry ... [at different point in interview] I feel that ... cap and trade or whatever it is, [is] payment to the government. They already take so much from us. At the end of the day there will be a tipping point that we have to hold off, not because we're not making money, is that we're to make enough to survive because the government takes a big cut" (Company P04).

"I suspect on the industry there's probably going to be some rude awakening, but I think for [brewery name] ... I think for the most part it won't have a tremendous impact on us personally" (Company P07).

Although cap and trade in Ontario may be cancelled under the current Provincial government, the discrepancy in perceived impacts of carbon regulation points to a lack of communication between government and small businesses. Better outreach and communications between government and small business owners would support a more unified understanding of how, or if, regulation will impact the financial bottom line of Ontario Craft Brewers.

Another barrier that was mentioned in the interviews was the time barrier $(n=2)$, which referred specifically to limited time in worker hours to dedicate to GHG accounting. Finally, one interviewee was unsure of any challenges to GHG accounting $(n=1)$.

\subsubsection{Interview Benefits to GHG Measurement and Reduction}

The main benefit to GHG management among the interviewees was marketing beer products as environmentally sustainable $(n=9)$. For example, the role of environmental management in a company's branding was explicitly raised by multiple participants. As one participant explained, “... lots of people talk about being socially environmentally aware and we can prove it, but we actually need to do more to ... we're not promoting as much as we should ... " (Company P12). Marketing the environmental sustainability of craft brewery products was likely appealing to these breweries due to potential reputational benefits, particularly given that, as one participant explained, " ... beer in particular is a relationship commodity" (Company P07). The same participant went onto further explain, " . . from top to bottom, corporate, good corporate citizenship has been a piece of [brewery name]'s branding" (Company P07). These branding opportunities could provide a basis for promotional efforts focused on consumer acquisition and retention.

Four of 13 interviewees said that a benefit to managing GHGs was improving environmental health. These interviewees wished to leave a positive legacy, avoid harming their community, and leaving a healthy planet for future generations. One representative comment in this area is, “... we're actually trying to make great beer but we're also trying to have a positive impact in the 
community, the environment and you know, and globally" (Company P12). Some of these interviewees stated that the health of the natural environment took precedence to a certain degree over business operations. For example, one participant commented:

"I understand that aspect of a business [i.e., increasing sales] and you have to run it but it's like, this transcends things like selling your product. It gets to the point of you know, just being like I said, good stewards of what we have here on earth ... " (Company P06).

Another benefit of GHG management shared by interviewees was an opportunity for cost savings $(n=5)$. One participant cited initiatives they've engaged in that reduces inputs such as energy, thus reducing GHGs while reducing costs: “... we are looking at other factors such as bringing a condenser in to actually reduce emissions. We plan to recirculate our spent water. So you know, we're looking to try an energy saving component" (Company P12). Finally, two participants could not identify any benefits of carbon management. In reference to unknown benefits of carbon management from a lack of knowledge, one participant stated: “ . . there's not a lot of money to put into research and development [of GHG reduction opportunities]" (Company P9).

\subsection{Case Study Results}

The goal of the case company portion of this research was to determine the GHG emissions of an Ontario craft brewer in order to provide deeper insight into the two research questions, particularly RQ1 focused on the challenges of measuring GHG emissions.

\subsubsection{Case Study Process Mapping}

The company's GHG emissions across its entire value chain were represented in process maps developed in accordance with published guidelines [56]. The process maps were developed over a period of several months and involved close consultation with personnel in the case company. The process mapping provided a basis for identifying the source of the company's GHG emissions, as well as the required primary and secondary data sources. The maps accounted for upstream, brewery, and downstream operations. Upstream processes included supplier production and transportation of raw materials to the brewery, brewery operations included those under direct control of the brewery, and downstream operations included transportation of waste, and returned products such as packaging. Due to confidentiality concerns, only a high-level process map can be presented here (Figure 1); more detailed process maps were made available to the case company.

\subsubsection{Case Study GHG Calculations}

The process maps provided a basis for calculating the case company's carbon footprint. The collection and analysis of the data involved hundreds of hours of effort over the course of several months. The results show that the craft brewer's largest source of GHG emissions was indirect sources, with scope 3 emissions accounting for $46.43 \%$ of GHG emissions and scope 2 accounting for $38.70 \%$ of GHGs. Direct emissions, i.e., scope 1, accounted for $14.87 \%$ of GHGs (see Figure 2). An important note is that the case company has significant carbon offsets, which reduced their scope 2 emissions by a factor of 2.8 .

GHG calculations were completed using primary and secondary data. Primary data collected from the case company is shown in Table A4. For example, to calculate transportation emissions from the case company, the amount and type of fuel used per year (in L) was multiplied with the emission factor to convert to $\mathrm{CO}_{2} \mathrm{e}$. As another transportation example, for brewery inputs that were shipped overseas, the supplier's location (to calculate distance shipped overseas) was multiplied with the percentage of the maximum load of the shipping freighter and fuel usage. The largest single source of scope 3 emissions was barley production, which accounted for $10.73 \%$ of all scope emissions. The largest single source of scope 2 GHGs was steam, contributing $21.05 \%$ to all scope emissions. 
Finally, gasoline was the largest single source of scope 1 GHGs, contributing $5.36 \%$ of all scope brewery emissions. The top three sources for each of scope 1, 2, and 3 GHGs are listed in Table 3.

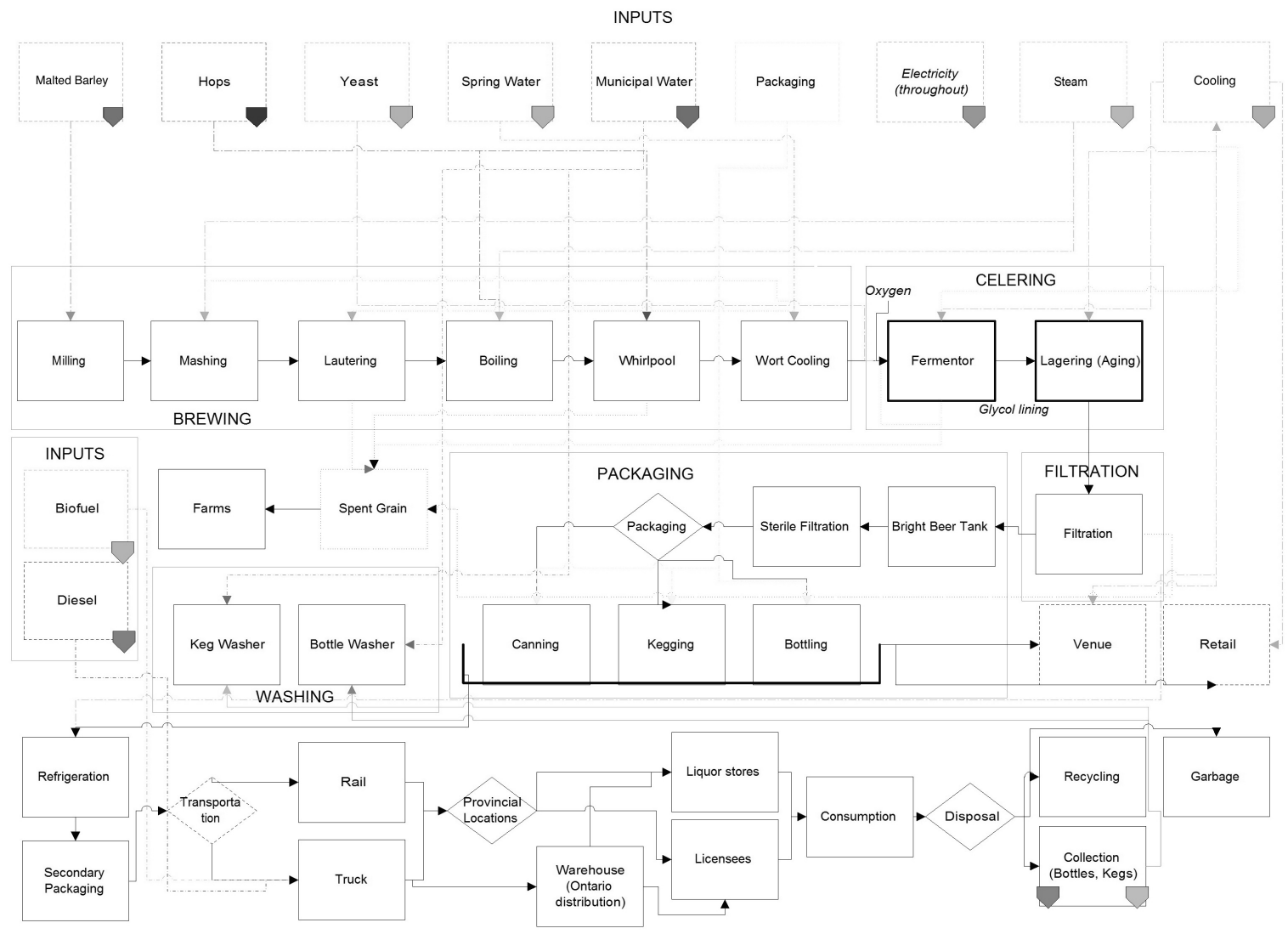

Figure 1. Process map of the case company brewery operations. Rectangle boxes encompass processes and/or products. Solid-lined boxes represent stages of the brewery's beer lifecycle, while dash-lined boxes represent beer inputs. Pathways of inputs through the brewery process are denoted with dashed lines. Solid lines connect the flow of processes through the brewery value chain. Data sources were obtained through the primary contact at the case company.

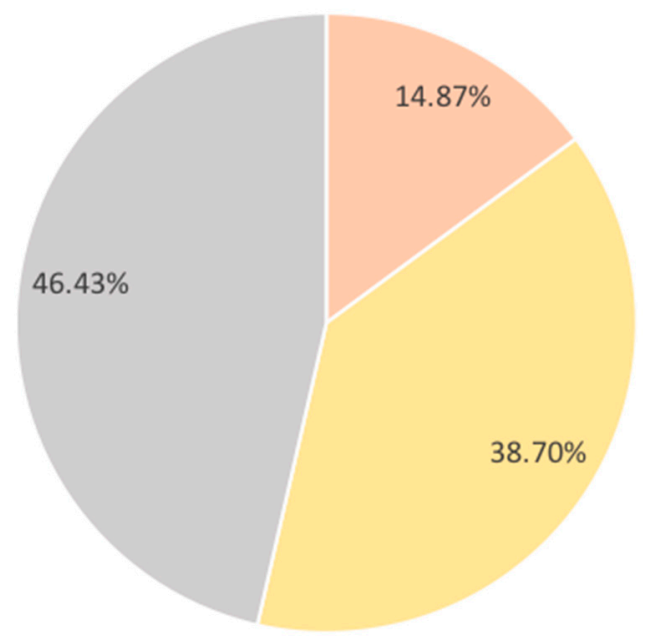

Figure 2. Breakdown of greenhouse gas emission sources by scope type. The red pie slice denotes scope 1 emissions, the yellow pie slice represents scope 2 emissions, and the grey pie slice is scope 3 emissions. Data used to calculate greenhouse gas emissions is from primary (case company) and secondary sources. 
Table 3. The three largest emission sources from each GHG scope is reported by source (product/process), scope (1, 2, 3, using GHG Protocol definitions $[23,48])$, amount of $\mathrm{CO}_{2}$ e per year, and percent of overall GHG emissions (the product/processes GHGs relative to all emissions). The "Percent of overall GHG emissions" column does not sum to $100 \%$ because only the top three sources from each GHG scope were included.

\begin{tabular}{ccccc}
\hline Source & Scope & Category & Tonnes CO $\mathbf{2}$ /Year & $\begin{array}{c}\text { Percent (\%) of Overall } \\
\text { GHG Emissions }\end{array}$ \\
\hline Diesel & Scope 1 & Mobile emissions & 178.98 & $4.20 \%$ \\
\hline Gasoline & Scope 1 & Mobile emissions & 228.43 & $5.36 \%$ \\
\hline B20 Biofuel & Scope 1 & Mobile emissions & 188.79 & $4.43 \%$ \\
\hline Steam & Scope 2 & Purchased steam & 897.61 & $21.05 \%$ \\
\hline Electricity & Scope 2 & Purchased electricity & 406.39 & $9.53 \%$ \\
\hline $\mathrm{CO}_{2}$ bulk liquid & Scope 2 & $\begin{array}{c}\text { Beverage production } \\
\text { and warehousing }\end{array}$ & 337.14 & $7.91 \%$ \\
\hline Barley agriculture & Scope 3 & Raw material processing & 457.56 & $7.80 \%$ \\
\hline $\begin{array}{c}\text { Malted barley } \\
\text { transportation }\end{array}$ & Scope 3 & Transportation and & 332.44 & $7.44 \%$ \\
\hline \multicolumn{7}{c}{ Malting } & Scope 3 & Raw matribution & $78.09 \%$ \\
\hline \multicolumn{7}{c}{ Percent GHGs from top three sources from each scope } \\
\hline
\end{tabular}

An important finding from the case study is also the distribution of GHGs along a craft brewery's value chain. The case study found a concentrated amount of GHGs, with the top three GHG sources from each of scope 1, 2, and 3 emission sources accounting for just over $78 \%$ of GHGs (Table 3). This information is useful for identifying major emission hot spots along the brewery's chain, and forming a plan of action to address major emission sources. Although this case study cannot be generalized to all Ontario Craft Brewers, it provides a starting point to understand and investigate large carbon emission sources among these companies' value chains.

\subsubsection{Case Study Scenario Analysis}

Based on consultation with the case company, one scenario analysis was conducted that calculated GHG emission changes by year 10 given varied projections of beer production growth and (relative to baseline) changes in percentage packaging of beer in glass bottles and aluminum cans. This scenario provided insight into the challenges and opportunities for reducing GHG emissions in the case company going forward. The formula for the scenario is summarized in Formula 1 and the results are summarized in Table 4.

Formula 1. Formula for scenario: Case company beer production growth $X$ (relative to baseline) percentage change to bottle and can packaging. A simplified (text) formula and complete (detailed) formula are colour-labeled for inter-formula comparison.

\section{Simplified Formula:}

$\mathrm{CO}_{2} \mathrm{e}_{2028}=\left[\mathrm{CO}_{2} \mathrm{e}\right.$ from bottles produced for packaging in year $2028-\mathrm{CO}_{2} \mathrm{e}$ saved from recycled bottles used to produce bottles in year 2028] $\left[\mathrm{CO}_{2} \mathrm{e}\right.$ from cans produced for packaging in year $2028-\mathrm{CO}_{2} \mathrm{e}$ saved from recycled cans used to produce cans in year 2028]

\section{Complete Formula:}

$\mathrm{CO}_{2} \mathrm{e}_{2028}=\left(2016 \mathrm{hL}\right.$ packaged in bottles $* 100(\mathrm{~L} / \mathrm{hL}) / .341(\mathrm{~L} /$ bottle $) *(10 \text { year compound } / 2)^{\ddagger}$ * \% growth) * (1-decrease in bottle packaging $) *$ weight bottle $(\mathrm{g}) / 1000(\mathrm{~g} / \mathrm{kg}) *(\%$ returned bottles

*EF for bottle recycled $+(99 \%$ returned bottles $) * \mathrm{EF}$ for new bottles $)$ 
$(2016 \mathrm{hL}$ packaged in cans * $100(\mathrm{~L} / \mathrm{hL}) /(0.473+0.355) / 2(\mathrm{~L} / \mathrm{can}) *(10$ year compound $/ 2) \ddagger$ * \% growth $) *(1+$ increase in can packaging $) *$ weight can $(\mathrm{g}) / 1000(\mathrm{~g} / \mathrm{kg}) *(\%$ returned cans $* \mathrm{EF}$ for can recycling $+(94 \%$ returned cans $) *$ EF for new cans $)$

$\ddagger$ the time horizon for this calculation is 10 years (2018-2028). Since the growth in beer sales value drawn from OCB (2018) reflected their growth over two years (2015-2017), the formula reflects five compounding periods (one every two years) instead of 10 (one per year).

Other notes: two sizes of aluminum cans are reflected in the $(0.473+0.355) / 2$ section of the formula to calculate the average volume of cans because the case company's primary data did not specify litres packaged in the two sizes of cans. The return rates of aluminum cans were $94 \%$, with all other recycled material having a return rate of $99 \%$ (Teotonio, 2013).

Table 4. Scenario analysis findings. Case company data and secondary data were used to calculate each cell in the matrices. The first variable, "Case company beer production (hL)" uses primary, intermediate, and advanced growth projections to estimate beer production in the year 2028. The second variable, "Change (in hL) in beer packaged in bottles vs. cans" uses primary, intermediate, and advanced growth projections to estimate the increase in can packaging and decrease in bottle packaging in the year 2028.

\begin{tabular}{lcccc}
\hline \multicolumn{5}{c}{ Scenario 1: 10-Year Horizon (2028): Tonnes $\mathrm{CO}_{2}$ e/Year in Year 2028 with Beer Production Estimates $x$ Bottle Versus Can } \\
Production Ratio
\end{tabular}

The packaging scenario found that at a production growth increase of $24 \%$, increasing beer can packaging by $20 \%$ while reducing bottle packaging by the same percent decreases the brewery's annual GHGs by 2028 by $14 \%$. Furthermore, under a period of advanced production growth $(30 \%$ over 10 years), if the brewery reduces their bottles by $20 \%$ and increases cans by $20 \%$, emissions can be lower than under a period of $18 \%$ growth over 10 years if no changes to packaging are made. These results suggest changes in beer packaging ratios can reduce total GHG emissions for the brewery under aggressive growth scenarios.

\subsubsection{Case Study Challenges and Benefits of GHG Reduction}

The GHG calculations and scenario analysis provide some insight into the challenges of measuring and reducing GHG emissions in OCBs. Aside from the time and resources needed to complete the case study, one key challenge in the GHG accounting was calculating scope 3 emissions. There were many uncertainties where primary data was not available, and secondary data was used. For example, GHGs from agricultural inputs to the case company, such as barley, hops, and yeast, were not widely available and when found in academic and industry papers, often varied. This was due primarily to the different geographic scope of studies, varying agricultural methods, and varying data collection methods. In these cases, there were no clear data sources to use. The most applicable data was collected and used where possible (i.e., similar geographic scope and year of study). When no appropriate secondary data was available, the scope was adjusted to exclude certain emitting processes in the supply chain. Specifically, retail merchandise (all merchandise aside from beer, including items such as glassware and clothing), office and administration materials, and secondary packaging were not included in the calculations. Primary and secondary data gaps were also an issue in limited instances. 
For example, while total fuel usage by the case company was available, missing information made it difficult to target where these emissions were along the supply chain. Relatedly, incomplete information on shipping of case company beer via different modes of transportation (truck versus other modes) made emission factor application difficult.

There were also challenges in the case study that arose from employee turnover and tacit knowledge. Considering the initial meeting with the case company to the study's completion, the study was completed over the course of 20 months. During this time, there was greater than expected turnover in the study's primary contact with the case company. Due to this turnover, there was tacit knowledge that did not get effectively communicated from the (two) outgoing to the incoming primary contact in the case company. For example, because implicit knowledge regarding the project was lost, it took time to update and work with the incoming primary contact. Implicit knowledge is defined as the unconscious learning by a person, who is thus unable to describe or transmit that learning [57]. Because of tacit knowledge loss, and employee turnover, project engagement was difficult to sustain. The loss of tacit knowledge could also be a key challenge for other craft brewers, given that they are all relatively small companies and most have relatively few environmentally-focused personnel.

During the initial meetings with the case company, the case company indicated that the motivation for undertaking this study was to advance their environmental actions to protect and promote their sustainable brand, and to keep in line with their mandate to reduce their business' environmental impact. The case company also explained that carbon accounting would be beneficial as it would provide a baseline of emissions that management could use to quantitatively and objectively set and measure carbon reduction goals. This process would maximize the impact of carbon reduction goals. Finally, by conducting the carbon accounting exercise, the case company would understand what their brewery's emissions currently are, and would be able to better plan for the possibility of carbon regulation that would apply to the case company in the future.

\section{Discussion}

Both the interviews and the case study provided a strong basis for addressing this study's two research questions. As the results illustrate, however, greater emphasis was placed on the challenges of accounting for GHG emissions than the benefits of doing so. This is not entirely surprising given the level of effort required to measure a company's carbon footprint, the fact that all of the craft brewers involved in the study were small companies, and that many of the brewers participating in the study were struggling to simply remain in business. The general emphasis on the challenges over the benefits highlights the need for proponents of GHG measurement and reduction in craft brewers to develop a strong business case for these initiatives. Craft brewers do not generally have a large amount of discretionary resources or specifically-designated environmental personnel and must therefore be particularly careful in determining which environmental initiatives to invest their time and resources in.

Cost was identified as the primary barrier to GHG measurement and accounting among Ontario craft brewers. This finding supports previous research in the literature which identified cost as a barrier to adopting GHG management policies and equipment in California's brewing industry [58]. Positive publicity or marketing was also identified as a benefit of an environmentally sustainable product [58]. The results from this study also support this finding, as it was found that 9 of 13 interviewees and the case company believe environmental sustainability marketing for their beer is a benefit of GHG emission reductions. Beyond the existing literature, this study identified other barriers and benefits to GHG reduction measures. In particular, a lack of human resources among interviewed breweries $(n=4)$, and limited technical capital and knowledge $(n=6)$ were identified as main challenges to GHG reduction. Regarding benefits, this study found that promoting the health of the environment was a main benefit of GHG reduction $(n=4)$, along with cost savings $(n=5)$.

The main challenges and benefits identified in this study are somewhat explained by institutional and image theory. Both coercive and mimetic pressures to reduce GHG emissions were found to 
be relatively weak. Ontario's cap and trade program, for example, did not appear to substantively influence GHG reduction efforts by the craft brewers participating in this study. Taxes more broadly were cited as a factor contributing to financial constraints by several participants, which, as they noted, restricted the resources they had available to advance environmental initiatives. The participants did express some interest in learning about what other craft breweries were doing, but it was also noted that there was a low awareness of initiatives in their industry. Opportunities to mimic the actions of other Ontario craft brewers were therefore limited. The research did provide some evidence that craft brewers experience moderate normative pressures to reduce their GHG emissions. For example, a number of interviewees and contacts in the case study indicated that both managers and employees within the craft breweries valued preserving the natural environment. Moreover, there is some evidence that breweries took action based, at least in part, on these values. Acting on their environmental values is also something further explained by image theory. For example, several breweries, particularly in the case study, did take action to measure and reduce their GHG emissions, even though they faced severe resource constraints. Reputational benefits arising from an improved brand image due to environmental initiatives were also noted by several study participants.

In addition to supporting these previous findings on challenges and benefits and findings anticipated by theory, this study provided deeper insight into the mechanics of GHG measurement in a craft brewery and the specific challenges of constructing a company's carbon footprint. The case study showed that the largest GHG emission sources were found in the purchased inputs for brewery processes. This is significant as the few efforts cited in the interviews and case study to address their GHG emissions primarily focus on direct GHGs (i.e., those directly emitted by a company's operations, such as fuel usage for a company's fleet). It is becoming increasingly clear, however, that indirect emissions account for the largest source of brewery GHGs. Although previous studies employed different methodologies and the specific results vary, the studies came to similar conclusions $[9,18,21,32]$. OCBs should therefore devote greater focus to measuring and reducing their indirect GHG emissions through, for example, looking for efficiencies in brewery energy inputs and alternative sources of energy. Other existing literature highlights opportunities to reduce GHG emissions in the alcohol industry by implementing carbon capture activities, and generating income by producing byproducts such as liquid carbon dioxide and calcium bicarbonate [59,60].

Given the challenges in measuring scope 3 emissions, this may be an area where OCBs could consider working together at the industry level. While there are many differences between individual companies, the sources of indirect emissions are broadly similar across the industry due, for example, to the need to use common resource inputs. The OCBA could consider coordinating industry-level efforts to measure indirect GHG emissions, particularly given that some interview participants indicated their interest in seeing the OCBA take a greater role in environmental leadership and education. An industry-level effort at GHG reduction could also provide the craft breweries with a greater ability to influence changes in supplier practices than if the small businesses took action independently. Individual craft brewers may lack the leverage necessary, through their relatively limited buying power, to compel changes in supplier practices. Pooling their efforts may help overcome this challenge.

Moreover, collective efforts may help craft breweries address several of the major challenges inherent in any GHG accounting process. As demonstrated in the case study, finding geographically, technologically, and age-appropriate secondary data for inputs and outputs of the craft brewing process is a difficult, time-consuming process. This aligns with previous research on calculating carbon footprints in the brewery industry $[1,5,9,21,32]$. In particular, both the case study and the previous research underline that the geographic setting is a critical consideration in carbon accounting, particularly due to its impacts on the calculation of scope 2 emissions. Scope 2 emissions are primarily a function of the forms of energy generation in the region, which highlights the need for regionally-specific approaches to the calculation of those emissions. Ontario craft brewers may 
consider working together to develop a database of scope 2 emissions based on the energy mix in the province.

Both the published literature and this study show that GHG accounting is highly variable when other factors beyond geography are considered, such as the method and scope, the scale of production, packaging choices, distance from suppliers, and fuel sources used, among other variables. For example, the findings from the case study found that steam constituted the largest source of GHG emissions (21.05\%). Bottle and can production represented $11.74 \%$ of GHGs, and total packaging contributed $12.30 \%$ of brewery emissions. Electricity was another major source of brewery emissions, accounting for $9.53 \%$ of total GHGs. The literature mainly found that packaging was the largest source of GHGs for the breweries studied. A UK-based study found that $19-46 \%$ of GHGs along the value chain of beer were attributed to beer packaging, which varies largely between packaging type [21]. Koroneos et al.'s research also suggests packaging is one of the main sources of GHGs along a brewery's supply chain [9]. The findings from the case study portion of study indicated that packaging and electricity use account for less when compared to calculations from previous literature. The findings from the case study's scenario analysis, however, supported the major impact of packaging decisions on GHG emissions. The scenario analysis results showed that under a $18 \%$ beer sales growth (the primary growth scenario), $\mathrm{a}+/-20 \%$ change in beer packaging (advanced packaging scenario) compared with no change to beer packaging (primary packaging scenario) resulted in a 12.5\% reduction in GHG emissions by 2028 (Table 4). To summarize, the scenario analysis showed that changes to packaging can significantly reduce GHG emissions, which is especially important under future growth scenarios.

\section{Conclusions}

The purpose of this study was to investigate the challenges and benefits of GHG carbon accounting and management among Ontario Craft Brewers. The interviews found that the two most common challenges are financial cost $(n=7)$, and limited human resources $(n=4)$. The top two benefits are opportunities for marketing a sustainable product $(n=9)$, and environmental health $(n=4)$. The case study found that scope 3 emissions accounted for the greatest proportion of the case company's emissions at $46.4 \%$ (indirect sources, from upstream and downstream of the case company), followed by scope 2 at $38.7 \%$ (associated primarily with emissions generated from heating and cooling operations), and finally scope 1 at $14.9 \%$ (emissions directly generated by the case company). The case study found the top three sources of emissions (respectively) were from steam use $(21.0 \%)$, barley agriculture $(10.4 \%)$, and purchased electricity $(9.5 \%)$. The case study reinforced that human resources are a key challenge in measuring GHG emissions, which are further exacerbated when employees holding tacit knowledge depart from a company. These findings offer useful insight for craft breweries looking to reduce their GHGs, and provide information for policy makers regarding gaps of knowledge and potential areas of interest OCB engagement.

This study has various academic, managerial, and societal contributions. Academically, this study contributes to the limited literature regarding the challenges and benefits of brewers' accounting and management of carbon emissions. Further, the perspective of small enterprises with limited resources adds value to this analysis. This study's quantitative findings also support the literature findings that indirect sources of GHGs are the major emitters in the supply chain. Managerially, the case study in particular adds value to practitioners by providing a framework and tools for how to calculate baseline carbon emissions and project or estimate future emissions based on present-day decisions. This study has particular value for small companies (and even more so for OCBs) with limited financial resources to begin understanding their carbon emissions and implement measures to reduce emissions. Finally, the research findings can be used as a starting point for government-initiated stakeholder research into how to engage meaningfully with craft breweries, and other SMEs, of the impacts of carbon regulation.

Future work should look to expand the interview population to include the OCBA and provincial government representatives to understand these governing bodies' priorities in terms of assisting OCBs to regulate their GHGs. This research could explore governing bodies' priorities with regards 
to knowledge sharing and financial resource assistance to help OCBs manage their GHG emissions, and compare this to the actual challenges experienced by OCBs. To help guide decision-making about GHG reduction efforts going forward, other scenario analyses could also be conducted. For example, future scenarios could explore the financial risk exposure faced by craft brewers over the shortand long-term due to climate change risks impacting, for example, their barley and hops suppliers. The impact of prioritizing local suppliers, where available, could also be explored from both a financial and GHG emissions change perspective. Finally, another recommendation for future work is to explore the role and influence of tacit knowledge in implementing GHG programs, or more widely environmental sustainability programs, among craft breweries. As noted, one challenge in the case study was the turnover of the principal contact. Further research is needed to determine the effect of employee turnover on organizational knowledge management of environmental issues in small organizations.

Author Contributions: Conceptualization, R.S. and C.S.; Data curation, R.S. and C.S.; Formal analysis, R.S.; Funding acquisition, C.S.; Investigation, R.S. and C.S.; Methodology, R.S. and C.S.; Project administration, R.S. and C.S.; Resources, C.S.; Supervision, C.S.; Validation, R.S.; Visualization, R.S.; Writing—original draft, R.S. and C.S.; Writing-review \& editing, R.S. and C.S.

Acknowledgments: The authors would like to thank the Natural Sciences and Engineering Research Council of Canada (NSERC) for supporting this research. The authors would also like to thank the case company and the interview participants.

Conflicts of Interest: The authors declare no conflict of interest.

\section{Appendix A}

Table A1. Ontario Craft Brewer member interview questions and sub-questions. Each interview question is alphabetized within the main interview question to show how the sub-questions were broken into units for analysis.

\begin{tabular}{cl}
$\begin{array}{c}\text { Interview } \\
\text { Question } \\
\text { Number }\end{array}$ & Interview Questions \\
\hline 1 & $\begin{array}{l}\text { A. Does your company measure its electricity usage? B. If so, does your company have } \\
\text { plans in place to minimize electricity use? C. Are you aware of your company's electricity } \\
\text { composition (i.e., percentage sourced from renewable vs. non-renewable energy)? }\end{array}$ \\
\hline 2 & $\begin{array}{l}\text { A. Does your company measure its greenhouse gas (GHG) emissions? B. If so, does your } \\
\text { company have any GHG reduction programs in place? C. What is your company's process } \\
\text { and considerations for developing GHG reduction targets? D. Do you measure direct and } \\
\text { indirect GHG emissions? }\end{array}$ \\
\hline 3 & $\begin{array}{l}\text { Do you see managing electricity use and reducing GHG emissions as priorities in your } \\
\text { business model? Why or why not? }\end{array}$ \\
\hline 5 & $\begin{array}{l}\text { Regardless of whether you collect baseline GHG emissions data, what do you see as the } \\
\text { main A. challenges and B. benefits of collecting baseline GHG emissions data? Prompt: for } \\
\text { example, do you see a marketing opportunity for promoting your beer as environmentally } \\
\text { sustainable for reducing its carbon footprint? Is cost a consideration? }\end{array}$ \\
\hline 5 & $\begin{array}{l}\text { A. Does your company have any sustainability initiatives? B. What are the main challenges } \\
\text { in implementing/maintaining these programs? C. If you do not have a program in place, } \\
\text { what are your reasons for opting not to? D. Do you foresee development of a program(s) in } \\
\text { the future? }\end{array}$ \\
\hline
\end{tabular}




\section{Appendix B}

Table A2. Keyword categories and their frequencies for the content analysis of Ontario Craft Brewer websites. Frequency refers to the number of times a keyword that is included in its respective keyword category was mentioned on an Ontario craft brewer website.

\begin{tabular}{|c|c|c|}
\hline Keyword Category & Keywords Included in the Category & $\begin{array}{l}\text { Frequency (\# Keywords } \\
\text { Included in Category) }\end{array}$ \\
\hline $\begin{array}{l}\text { Environmental } \\
\text { sustainability }\end{array}$ & $\begin{array}{l}\text { Accountability, B-Corps, carbon neutral, eco-friendly, } \\
\text { environmental impact, environmental performance, } \\
\text { environmental sustainability, environmentally } \\
\text { conscious, environmentally responsible, green, } \\
\text { sustainable, sustainable environmental best practices }\end{array}$ & 16 \\
\hline $\begin{array}{l}\text { Supply chain } \\
\text { management }\end{array}$ & $\begin{array}{l}\text { Biodiesel, closed loop, green electricity, grown on } \\
\text { site, ink reduction, local, locally sourced, } \\
\text { low-emission heating and cooling, renewable energy, } \\
\text { renewable power, responsibly sourced, sustainably } \\
\text { sourced energy }\end{array}$ & 13 \\
\hline Input efficiency & $\begin{array}{l}\text { Paper reduction, reduce energy usage, remove } \\
\text { chemical usage, water conservation }\end{array}$ & 4 \\
\hline Waste reduction & $\begin{array}{l}\text { Compost, nothing goes to waste, organic waste, } \\
\text { waste diversion }\end{array}$ & 4 \\
\hline Responsible packaging & Reusable bottles, sustainable packaging & 2 \\
\hline $\begin{array}{l}\text { Environmental } \\
\text { behaviour }\end{array}$ & $\begin{array}{l}\text { Clean commute, employee education, re-use, } \\
\text { recyclable, recycle, transparency }\end{array}$ & 7 \\
\hline Total keywords & & 46 \\
\hline
\end{tabular}




\section{Appendix C}

Table A3. Secondary emission factor data, and sources, used for case study greenhouse gas calculations.

\begin{tabular}{|c|c|c|c|c|}
\hline Product/Process & Emission Factor & Emission Factor Unit & Source/Standard & Table/Figure/Page \\
\hline Steel production & 0.07 & tonnes $\mathrm{CO}_{2} /$ tonne steel & $\begin{array}{l}2017 \text { Canadian National Inventory Submission to the United } \\
\text { Nations Framework Convention on Climate Change } \\
\text { (using } 2015 \text { inventory) }\end{array}$ & Table 2(I).A-Hs2 \\
\hline Steam production & 67.800 & $\mathrm{kgCO}_{2} \mathrm{e} / 1000 \mathrm{lbs}$ steam & $\begin{array}{l}\text { Rolff, D. (2011). LCA of deep lake water cooling in Toronto. } \\
\text { (Unpublished master's paper). University of Toronto, } \\
\text { Toronto, Canada. }\end{array}$ & Page 18 \\
\hline Refrigeration and cooling & 0.040 & $\mathrm{kgCO}_{2} \mathrm{e} /$ tonne hour & $\begin{array}{l}\text { Rolff, D. (2011). LCA of deep lake water cooling in Toronto. } \\
\text { (Unpublished master's paper). University of Toronto, } \\
\text { Toronto, Canada. }\end{array}$ & Page 22 \\
\hline $\begin{array}{l}\text { Fuel consumption for Class } \\
7 \text { and } 8 \text { vehicles }\end{array}$ & 0.39 & $\mathrm{~L} / \mathrm{km}$ & $\begin{array}{l}2017 \text { Canadian National Inventory Submission to the United } \\
\text { Nations Framework Convention on Climate Change } \\
\text { (using } 2015 \text { inventory) }\end{array}$ & Table 1.A(a)s3 \\
\hline Road diesel & 10.131 & $\mathrm{~kg} \mathrm{CO} / \mathrm{US}$ gallon & WRI Emission Factors from Cross Sector Tools, 2017 & $\mathrm{CO}_{2}$ for road diesel fuel: Table 12 \\
\hline Road diesel & 2.676327 & $\mathrm{~kg} \mathrm{CO}_{2} / \mathrm{L}$ diesel & (conversion) WRI Emission Factors from Cross Sector Tools, 2017 & $\mathrm{CO}_{2}$ for road diesel fuel: Table 12 \\
\hline Gasoline/petrol & 8.59873 & $\mathrm{~kg} \mathrm{CO} /$ US gallon & WRI Emission Factors from Cross Sector Tools 2017 & $\mathrm{CO}_{2}$ for gasoline/petrol: Table 12 \\
\hline Gasoline/petrol & 2.271544 & $\mathrm{~kg} \mathrm{CO} / \mathrm{L}$ gasoline & (conversion) WRI Emission Factors from Cross Sector Tools, 2017 & $\mathrm{CO}_{2}$ for gasoline/petrol: Table 12 \\
\hline Jet fuel & 9.428 & $\mathrm{~kg} \mathrm{CO} / \mathrm{US}$ gallon & WRI Emission Factors from Cross Sector Tools 2017 & $\mathrm{CO}_{2}$ for jetfuel: Table 12 \\
\hline Jet fuel emissions & 0.61324 & $\mathrm{~kg} \mathrm{CO} /$ tonne $\mathrm{km}$ & WRI Emission Factors from Cross Sector Tools 2017 & Table 16 \\
\hline Rail transportation & 0.0252 & $\mathrm{~kg} \mathrm{CO}_{2} /$ short tonne mile & WRI Emission Factors from Cross Sector Tools 2017 & $\mathrm{CO}_{2}$ for rail transportation: Table 16 \\
\hline Rail transportation & $2.77782 \times 10^{-5}$ & $\mathrm{~kg} \mathrm{CO}_{2} / \mathrm{kg}$ mile & WRI Emission Factors from Cross Sector Tools 2017 & $\mathrm{CO}_{2}$ for rail transportation: Table 16 \\
\hline $\begin{array}{l}\text { Ocean container } \\
\text { transportation }\end{array}$ & 0.048 & $\mathrm{~kg} \mathrm{CO}_{2} /$ short tonne mile & WRI Emission Factors from Cross Sector Tools 2017 & Table 16 \\
\hline $\begin{array}{l}\text { Ocean container } \\
\text { transportation }\end{array}$ & $3.286 \times 10^{-5}$ & $\mathrm{~kg} \mathrm{CO}_{2} / \mathrm{kg} \mathrm{km}$ & (converted) WRI Emission Factors from Cross Sector Tools 2017 & Table 16 \\
\hline Biofuel & 8.10442 & $\mathrm{~kg} / \mathrm{US}$ gallon biodiesel & WRI Emission Factors from Cross Sector Tools 2017 & $\mathrm{CO}_{2}$ for biofuel: Table 12 \\
\hline Biofuel & 2.140961 & $\mathrm{~kg} / \mathrm{L}$ biodiesel & (Converted) WRI Emission Factors from Cross Sector Tools 2017 & $\mathrm{CO}_{2}$ for biofuel: Table 12 \\
\hline
\end{tabular}


Table A3. Cont.

\begin{tabular}{|c|c|c|c|c|}
\hline Product/Process & Emission Factor & Emission Factor Unit & Source/Standard & Table/Figure/Page \\
\hline Waste to landfill & 0.05 & tonnes $\mathrm{CH}_{4} /$ tonne waste & $\begin{array}{l}2017 \text { Canadian National Inventory Submission to the United } \\
\text { Nations Framework Convention on Climate Change } \\
\text { (using } 2015 \text { inventory) }\end{array}$ & Table 5.a \\
\hline Waste to landfill & 1.40 & tonnes $\mathrm{CO}_{2} \mathrm{e} /$ tonne waste & $\begin{array}{l}\text { (conversion) } 2017 \text { Canadian National Inventory Submission to the } \\
\text { Climate Change (using } 2015 \text { inventory) }\end{array}$ & United Nations Framework Convention on \\
\hline Waste incinerated & 413.57 & $\mathrm{kt} \mathrm{CO}_{2} / \mathrm{kt}$ waste & $\begin{array}{l}2017 \text { Canadian National Inventory Submission to the United } \\
\text { Nations Framework Convention on Climate Change } \\
\text { (using } 2015 \text { inventory) }\end{array}$ & Table 5.a \\
\hline Waste incinerated & 0.26 & $\mathrm{kt} \mathrm{CH}_{4} / \mathrm{kt}$ waste & $\begin{array}{l}2017 \text { Canadian National Inventory Submission to the United } \\
\text { Nations Framework Convention on Climate Change } \\
\text { (using } 2015 \text { inventory) }\end{array}$ & Table 5 \\
\hline Waste incinerated & 0.44 & kt $\mathrm{N}_{2} \mathrm{O} / \mathrm{kt}$ waste & $\begin{array}{l}2017 \text { Canadian National Inventory Submission to the United } \\
\text { Nations Framework Convention on Climate Change } \\
\text { (using } 2015 \text { inventory) }\end{array}$ & Table 5 \\
\hline Organic compost & 21.89 & $\mathrm{kt} \mathrm{CH}_{4} / \mathrm{kt}$ waste & $\begin{array}{l}2017 \text { Canadian National Inventory Submission to the United } \\
\text { Nations Framework Convention on Climate Change } \\
\text { (using } 2015 \text { inventory) }\end{array}$ & Table 5 \\
\hline Organic compost & 1.31 & $\mathrm{kt}_{2} \mathrm{O} / \mathrm{kt}$ waste & $\begin{array}{l}2017 \text { Canadian National Inventory Submission to the United } \\
\text { Nations Framework Convention on Climate Change } \\
\text { (using } 2015 \text { inventory) }\end{array}$ & Table 5 \\
\hline Freight truck fuel efficiency & 2.676326532 & $\mathrm{~kg} \mathrm{CO}_{2} / \mathrm{L}$ diesel & WRI Emission Factors from Cross Sector Tools 2017 & $\begin{array}{l}\text { GHG Protocol emission factors from cross } \\
\text { sector tools March } 2017\end{array}$ \\
\hline Max load Class $7 / 8$ vehicle & $13,381.50$ & $\mathrm{~kg} /$ truck load & https://en.wikipedia.org/wiki/Truck_classification & US GVWR truck classifications \\
\hline $\mathrm{CH}_{4}(\mathrm{GWP})$ & 28 & $\mathrm{~g} \mathrm{CO}_{2} \mathrm{e} / \mathrm{g} \mathrm{CH} 4$ & $\begin{array}{l}2014 \text { IPCC GWP (AR5) found in IPCC } 2014 \text { Climate Change } \\
\text { report and GHG Protocol "Global Warming Potential Values" }\end{array}$ & Box 3.2, Page 87 \\
\hline $\mathrm{CO}_{2}$ (GWP) & 1 & $\mathrm{~g} \mathrm{CO}_{2} \mathrm{e} / \mathrm{g} \mathrm{CO} 2$ & $\begin{array}{l}2014 \text { IPCC GWP (AR5) found in IPCC } 2014 \text { Climate Change } \\
\text { report and GHG Protocol "Global Warming Potential Values" }\end{array}$ & Box 3.2, Page 88 \\
\hline $\mathrm{N}_{2} \mathrm{O}$ (GWP) & 265 & $\mathrm{~g} \mathrm{CO}_{2} \mathrm{e} / \mathrm{g} \mathrm{N} 2 \mathrm{O}$ & $\begin{array}{l}2014 \text { IPCC GWP (AR5) found in IPCC } 2014 \text { Climate Change } \\
\text { report and GHG Protocol "Global Warming Potential Values" }\end{array}$ & Box 3.2, Page 89 \\
\hline Paper packaging waste & 1.34 & $\mathrm{~kg} \mathrm{CO} \mathrm{CO}_{2} / \mathrm{kg}$ waste & BUWAL 250; Ecoinvent & Table 1, Cimini \& Moresi, 2016 \\
\hline Cardboard packaging waste & 1.73 & $\mathrm{~kg} \mathrm{CO} 2 \mathrm{e} / \mathrm{kg}$ waste & BUWAL 250; Ecoinvent & Table 1, Cimini \& Moresi, 2016 \\
\hline Paper recycling & -0.0635 & $\mathrm{kgCO}_{2} \mathrm{e} / \mathrm{kg}$ recycled & BUWAL 250; Ecoinvent & Table 1, Cimini \& Moresi, 2016 \\
\hline
\end{tabular}


Table A3. Cont.

\begin{tabular}{|c|c|c|c|c|}
\hline Product/Process & Emission Factor & Emission Factor Unit & Source/Standard & Table/Figure/Page \\
\hline $\begin{array}{l}\text { Plastic recycling } \\
\text { (includes PE, not PVC) }\end{array}$ & -0.332 & $\mathrm{~kg} \mathrm{CO}_{2} \mathrm{e} / \mathrm{kg}$ recycled & BUWAL 250; Ecoinvent & Table 1, Cimini \& Moresi, 2016 \\
\hline Glass recycling & -0.376 & $\mathrm{~kg} \mathrm{CO}_{2} \mathrm{e} / \mathrm{kg}$ recycled & BUWAL 250 & Table 1, Cimini \& Moresi, 2016 \\
\hline Aluminum recycling & -10.6 & $\mathrm{~kg} \mathrm{CO}_{2} \mathrm{e} / \mathrm{kg}$ recycled & BUWAL 250 & Table 1, Cimini \& Moresi, 2016 \\
\hline Steel recycling & -1.69 & $\mathrm{~kg} \mathrm{CO}_{2} \mathrm{e} / \mathrm{kg}$ recycled & BUWAL 250 & Table 1, Cimini \& Moresi, 2016 \\
\hline Aluminum can production & 1.75 & tonnes $\mathrm{CO}_{2} /$ tonne aluminum & $\begin{array}{l}2017 \text { Canadian National Inventory Submission to the United } \\
\text { Nations Framework Convention on Climate Change } \\
\text { (using } 2015 \text { inventory) }\end{array}$ & Table 2(I).A \\
\hline $\begin{array}{l}\text { Aluminum can }(50 \% \\
\text { recycled) production }\end{array}$ & 8.96 & $\mathrm{~kg} \mathrm{CO}_{2} \mathrm{e} / \mathrm{kg}$ can produced & International Aluminum Institute, 2013 & Table 1, Cimini \& Moresi, 2016 \\
\hline $\begin{array}{l}\text { Aluminum can ( } 99 \% \text { purity) } \\
\text { production }\end{array}$ & 11.5 & $\mathrm{~kg} \mathrm{CO}_{2} \mathrm{e} / \mathrm{kg}$ can produced & Idemat 2001 & Table 1, Cimini \& Moresi, 2016 \\
\hline Green glass (net) & 0.314 & $\mathrm{~kg} \mathrm{CO}_{2} \mathrm{e} / \mathrm{kg}$ glass & Turner, Williams \& Kemp, 2015 & $\begin{array}{l}\text { Table 6, calculated from study LCA (and in } \\
\text { same Table, literature values listed) }\end{array}$ \\
\hline Green glass (gross) & 0.395 & $\mathrm{~kg} \mathrm{CO}_{2} \mathrm{e} / \mathrm{kg}$ green glass & Turner, Williams \& Kemp, 2015 & $\begin{array}{l}\text { Table 6, calculated from study LCA (and in } \\
\text { same Table, literature values listed) }\end{array}$ \\
\hline Brown glass (net) & 0.314 & $\mathrm{~kg} \mathrm{CO}_{2} \mathrm{e} / \mathrm{kg}$ glass & Turner, Williams \& Kemp, 2015 & $\begin{array}{l}\text { Table 6, calculated from study LCA (and in } \\
\text { same Table, literature values listed) }\end{array}$ \\
\hline Brown glass (gross) & 0.395 & $\mathrm{~kg} \mathrm{CO}_{2} \mathrm{e} / \mathrm{kg}$ glass & Turner, Williams \& Kemp, 2015 & $\begin{array}{l}\text { Table 6, calculated from study LCA (and in } \\
\text { same Table, literature values listed) }\end{array}$ \\
\hline Aluminum cans (net) & 8.143 & $\mathrm{kgCO}_{2} \mathrm{e} / \mathrm{kg}$ & Turner, Williams \& Kemp, 2015 & $\begin{array}{l}\text { Table 6, calculated from study LCA (and in } \\
\text { same Table, literature values listed) }\end{array}$ \\
\hline Aluminum cans (gross) & 1.113 & $\mathrm{kgCO}_{2} \mathrm{e} / \mathrm{kg}$ & Turner, Williams \& Kemp, 2015 & $\begin{array}{l}\text { Table 6, calculated from study LCA (and in } \\
\text { same Table, literature values listed) }\end{array}$ \\
\hline Mixed plastics (net) & 1.024 & $\mathrm{kgCO}_{2} \mathrm{e} / \mathrm{kg}$ & Turner, Williams \& Kemp, 2015 & $\begin{array}{l}\text { Table 6, calculated from study LCA (and in } \\
\text { same Table, literature values listed) }\end{array}$ \\
\hline Mixed plastics (gross) & 0.339 & $\mathrm{kgCO}_{2} \mathrm{e} / \mathrm{kg}$ & Turner, Williams \& Kemp, 2015 & $\begin{array}{l}\text { Table 6, calculated from study LCA (and in } \\
\text { same Table, literature values listed) }\end{array}$ \\
\hline $\begin{array}{l}\text { Barley (produced Europe or } \\
\text { USA) }\end{array}$ & 0.26 & $\mathrm{kgCO}_{2} \mathrm{e} / \mathrm{kg}$ & BIER (2012) & Table 1, Cimini \& Moresi, 2016 \\
\hline Barley Malting & $0.292( \pm) 0.084$ & $\mathrm{~kg} \mathrm{CO}_{2} \mathrm{e} / \mathrm{kg}$ & Chicago Manufacturing Centre (2009) & Table 1, Cimini \& Moresi, 2016 \\
\hline
\end{tabular}


Table A3. Cont.

\begin{tabular}{|c|c|c|c|c|}
\hline Product/Process & Emission Factor & Emission Factor Unit & Source/Standard & Table/Figure/Page \\
\hline Barley malting & 0.000256277 & $\mathrm{kWh} / \mathrm{g}$ malt & The Climate Conservancy (2008) & $\begin{array}{l}\text { The Carbon Footprint of Fat Tire Amber } \\
\text { Ale (report) }\end{array}$ \\
\hline Fermentation & 15 & $\mathrm{~g} \mathrm{CO} 2 / 473.176 \mathrm{~mL}$ & $\begin{array}{l}\text { https://www.theguardian.com/environment/green-living- } \\
\text { blog/2010/jun/04/carbon-footprint-beer }\end{array}$ & $\begin{array}{l}\text { Value taken from book "How Bad are } \\
\text { Bananas?: The Carbon Footprint of } \\
\text { Everything" by Mark Berners-Lee (2010) }\end{array}$ \\
\hline Hops emissions & 11.492766 & $\mathrm{~g} \mathrm{CO}_{2} \mathrm{e} / \mathrm{L}$ beer & The Climate Conservancy (2008) & $\begin{array}{l}\text { The Carbon Footprint of Fat Tire Amber } \\
\text { Ale (report) }\end{array}$ \\
\hline $\begin{array}{l}\text { Max number of containers } \\
\text { on ocean freighter }\end{array}$ & 10,000 & TEU/freighter ship & https://en.wikipedia.org/wiki/Container_ship & $\begin{array}{l}\text { (TEU = Twenty-foot equivalent container } \\
\text { units) }\end{array}$ \\
\hline $\begin{array}{l}\text { Max weight of one container } \\
\text { on ocean freighter }\end{array}$ & $16,727,256$ & $\mathrm{~g} /$ container & https://en.wikipedia.org/wiki/Container_ship & $\begin{array}{l}\text { (TEU = Twenty-foot equivalent container } \\
\text { units) }\end{array}$ \\
\hline bottle cap weights & 2.2 & g steel/bottle cap & & \\
\hline $355 \mathrm{~mL}$ can weight & 14.9 & g aluminum/aluminum can & & \\
\hline $473 \mathrm{~mL}$ can weight & 18.79 & g aluminum/aluminum can & & \\
\hline Nuclear power generation & 0.15 & $\mathrm{~g} \mathrm{CO}_{2} \mathrm{e} / \mathrm{kWh}$ & Intrinsik Corporation (2016) & Table E-1, page ii \\
\hline $\begin{array}{l}\text { Natural gas power } \\
\text { generation }\end{array}$ & 525.00 & $\mathrm{~g} \mathrm{CO}_{2} \mathrm{e} / \mathrm{kWh}$ & Intrinsik Corporation (2016) & Table E-1, page ii \\
\hline Hydro power generation & 0.00 & $\mathrm{~g} \mathrm{CO}_{2} \mathrm{e} / \mathrm{kWh}$ & Intrinsik Corporation (2016) & Table E-1, page ii \\
\hline Wind power generation & 0.74 & $\mathrm{~g} \mathrm{CO}_{2} \mathrm{e} / \mathrm{kWh}$ & Intrinsik Corporation (2016) & Table E-1, page ii \\
\hline Biofuel power generation & 0.17 & $\mathrm{~kg} \mathrm{CO}{ }_{2} \mathrm{e} / \mathrm{kWh}$ & Intrinsik Corporation (2016) & Table E-1, page ii \\
\hline Solar power generation & 6.15 & $\mathrm{~g} \mathrm{CO}_{2} \mathrm{e} / \mathrm{kWh}$ & Intrinsik Corporation (2016) & Table E-1, page ii \\
\hline
\end{tabular}




\section{Appendix D}

Table A4. Primary data collected and used from the case company for the GHG calculations.

\begin{tabular}{ccc}
\hline Data Name & Data Type and/or Scope & Source \\
\hline Electricity purchased & Primary data, Scope 2 & \\
Fuel purchased & Primary data, Scope 1 & \\
Hops purchased & Primary data, Scope 3 & \\
Spring water purchased & Primary data, Scope 3 & \\
Municipal water used & Primary data, Scope 3 & \\
Waste generated & Primary data, Scope 1 & \\
Steam purchased & Primary data, Scope 2 & Case company primary \\
Carbon dioxide purchased & Primary data, Scope 1 & contact, 2016 and 2017 \\
Glass bottles purchased & Primary data, Scope 3 & \\
Aluminum cans purchased & Primary data, Scope 3 & \\
Kegs purchased & Primary data, Scope 3 & \\
Secondary packaging purchased & Primary data, Scope 3 & \\
Return percentage of kegs and bottles & Primary data, Scope 2 and 3 & \\
Supplier information (location, number & Primary data, Scope 3 & \\
of shipments per year) & Primary data, Scope 3 & \\
Shipment method for each supplier & & \\
\hline
\end{tabular}

\section{References}

1. Olajire, A.A. The brewing industry and environmental challenges. J. Clean. Prod. 2012. [CrossRef]

2. Statista. Beer Industry-Statistics \& Facts. Available online: https://www.statista.com/topics/1654/ beerproduction-and-distribution/ (accessed on 22 October 2018).

3. Gómez-Corona, C.; Escalona-Buendía, H.B.; García, M.; Chollet, S.; Valentin, D. Craft vs. industrial: Habits, attitudes and motivations towards beer consumption in Mexico. Appetite 2016, 96, 358-367. [CrossRef] [PubMed]

4. Institute for Prospective Technological Studies (IPTS). Environmental Impact of Products (EIPRO): Analysis of the Life Cycle Environmental Impacts Related to the Final Consumption of the EU-25. 2005. Available online: ec.europa.eu/environment/ipp/pdf/eipro_report.pdf (accessed on 22 October 2018).

5. Cimini, A.; Moresi, M. Carbon footprint of a pale lager packed in different formats: Assessment and sensitivity analysis based on transparent data. J. Clean. Prod. 2016, 112, 4196-4213. [CrossRef]

6. Cordella, M.; Tugnoli, A.; Spadoni, G.; Santarelli, F.; Zangrando, T. LCA of an Italian lager beer. Int. J. Life Cycle Assess. 2008, 13, 133-139. [CrossRef]

7. Sturm, B.; Hugenschmidt, S.; Joyce, S.; Hofacker, W.; Roskilly, A.P. Opportunities and barriers for efficient energy use in a medium-sized brewery. Appl. Therm. Eng. 2013, 53, 397-404. [CrossRef]

8. Rajaniemi, M.; Mikkola, H.; Ahokas, J. Greenhouse gas emissions from oats, barley, wheat and rye production. Agron. Res. 2011, 1, 189-195.

9. Koroneos, C.; Roumbas, G.; Gabari, Z.; Papagiannidou, E.; Moussiopoulos, N. Life cycle assessment of beer production in Greece. J. Clean. Prod. 2005, 13, 433-439. [CrossRef]

10. Mozny, M.; Tolasz, R.; Nekovar, J.; Sparks, T.; Trnka, M.; Zalud, Z. The impact of climate change on the yield and quality of Saaz hops in the Czech Republic. Agric. For. Meteorol. 2009, 149, 913-919. [CrossRef]

11. Crowell, C. Bad News about This Year's Barley Crop. 2014. Available online: https://www. craftbrewingbusiness.com/ingredients-supplies/bad-news-years-barley-crop/ (accessed on 22 October 2018).

12. Beverage Industry Environmental Roundtable (BIER). Beverage Industry Continues to Drive Improvement in Water and Energy Use: 2016 Trends and Observations. 2016. Available online: http:/ /www.bieroundtable. com/blank-c1gkm (accessed on 22 October 2018).

13. Beverage Industry Environmental Roundtable (BIER). Joint Commitment on Climate Change. 2015. Available online: https: / www.bieroundtable.com/single-post/2015/05/20/BIER-Releases-Joint-Commitment-onClimate-Change (accessed on 22 October 2018). 
14. Ontario Craft Brewers Association (OCB). Ontario Craft Brewer's Strategic Plan, 2018-2027. 2018. Available online: http:/ / www.ontariocraftbrewers.com/About.html (accessed on 22 October 2018).

15. Rice, J. Professional purity: Revolutionary writing in the craft beer industry. J. Bus. Tech. Commun. 2016, 30, 236-261. [CrossRef]

16. Aquilani, B.; Laureti, T.; Poponi, S.; Secondi, L. Beer choice and consumption determinants when craft beers are tasted: An exploratory study of consumer preferences. Food Qual. Preference 2015, 41, 214-224. [CrossRef]

17. Beverage Industry Environmental Roundtable (BIER). Research on the Carbon Footprint of Beer. 2012. Available online: http:/ / www.bieroundtable.com/energy--climate (accessed on 22 October 2018).

18. Cimini, A.; Moresi, M. Effect of brewery size on the main process parameters and cradle-to-grave carbon footprint of lager beer. J. Ind. Ecol. 2018, 22, 1139-1154. [CrossRef]

19. Williams, A.G.; Mekonen, S. Environmental performance of traditional beer production in a micro-brewery. In Proceedings of the 9th International Conference on Life Cycle Assessment in the Agri-Food Sector, San Francisco, CA, USA, 8-10 October 2014; Schenck, R., Huizenga, D., Eds.; American Center for Life Cycle Assessment: Vashon, DC, USA, 2014; pp. 1535-1540.

20. Lalonde, S.; Nicholson, A.; Schenck, R. Life Cycle Assessment of Beer in Support of an Environmental Product Declaration. Institute for Environmental Research and Education (IERE), 2013. Available online: http:/ /iere.org/wp-content/uploads/2013/10/IERE_Beer_LCA_Final.pdf (accessed on 10 December 2017).

21. Amienyo, D.; Azapagic, A. Life cycle environmental impacts and costs of beer production and consumption in the UK. Int. J. Life Cycle Assess. 2016, 21, 492-509. [CrossRef]

22. Tan, D.; Benni, D.; Liani, W. Determinants of corporate social responsibility disclosure and investor reaction. Int. J. Econ. Financ. Issues 2016, 6, 11-17.

23. World Business Council for Sustainable Development and World Resources Institute (WBCSD \& WRI). The Greenhouse Gas Protocol: A Corporate Accounting and Reporting Standard. 2004. Available online: http:/ / ghgprotocol.org/ corporate-standard (accessed on 22 October 2018).

24. Food and Agriculture Organization of the United Nations (FAO). FAO Agribusiness Handbook: Barley, Malt and Beer. 2009. Available online: http://www.fao.org/fileadmin/user_upload/tci/docs/AH3_ BarleyMaltBeer.pdf (accessed on 22 October 2018).

25. Fish, H. Effects of the craft beer boom in Virginia: How breweries, regulators, and the public can collaborate to mitigate environmental impacts. William Mary Environ. Law Policy Rev. 2015, 40, 273-304. [CrossRef]

26. Hoalst-Pullen, N.; Patterson, M.W.; Mattord, R.A.; Vest, M.D. Sustainability trends in the regional craft beer industry. In The Geography of Beer; Springer Science and Business Media: Dordrecht, The Netherlands, 2014; pp. 109-116.

27. Molson Coors. Environmental, Social and Governance Report. 2017. Available online: http://www. molsoncoors.com/-/media/molson-coors-corporate/sustainability/esg-report-en.ashx (accessed on 22 October 2018).

28. New Belgium Brewing. Carbon Emissions. 2017. Available online: http://www.newbelgium.com/ Sustainability /Environmental-Metrics/GHG (accessed on 22 October 2018).

29. Muster-Slawitsch, B.; Hubmann, M.; Murkovic, M.; Brunner, C. Process modelling and technology evaluation in brewing. Chem. Eng. Process. 2014, 84, 98-108. [CrossRef]

30. Beverage Industry Environmental Roundtable (BIER). BIER: About. Available online: http://www. bieroundtable.com/about1 (accessed on 22 October 2018).

31. Beverage Industry Environmental Roundtable (BIER). Beverage Industry Sector Guidance for Greenhouse Gas Emissions Reporting (Version 3.0). 2013. Available online: http:/ /www.bieroundtable.com/energy-climate (accessed on 22 October 2018).

32. The Climate Conservancy. The Carbon Footprint of Fat Tire ${ }^{\circledR}$ Amber Ale. 2008. Available online: http: / / www.ess.uci.edu/ sjdavis/pubs/Fat_Tire_2008.pdf (accessed on 22 October 2018).

33. Baldwin, R. Regulation lite: The rise of emissions trading. Regul. Gov. 2008, 2, 193-215. [CrossRef]

34. Harrison, K. A tale of two taxes: The fate of environmental tax reform in Canada. Rev. Policy Res. 2012, 29, 383-407. [CrossRef]

35. Ontario Ministry of the Environment and Climate Change. Chapter 4: Cap and Trade. 2016. Available online: https:/ / media.assets.eco.on.ca/web/2016/11/2016-Annual-GHG-Report_Chapter-4.pdf (accessed on 22 October 2018). 
36. Ontario Regulation 144/16: The Cap and Trade Program. Filed under the Climate Change Mitigation and Low Carbon Economy Act. Government of Ontario, 2016. Available online: https:/ /www.ontario.ca/laws / regulation/r16144 (accessed on 22 October 2018).

37. Syed, F. Here's What You Need to Know about Ontario's Termination of Cap and Trade. Canada's National Observer, 2018. Available online: https:/ / www.nationalobserver.com/2018/11/01/news/ontario-cancelledits-cap-and-trade-program-amid-contradictions-and-inaccuracies-now (accessed on 22 October 2018).

38. Ontario Craft Brewers Association (OCB). OCB Breweries List. 2018. Available online: http://www. ontariocraftbrewers.com/breweriesList.php (accessed on 1 February 2018).

39. Ontario Craft Brewers Association (OCB). Ontario Craft Brewers-Industry Fact Sheet. 2018. Available online: www.ontariocraftbrewers.com/pdf/media_IndustryFactSheet.pdf (accessed on 15 January 2018).

40. Comyns, B. Climate change reporting and multinational companies: Insights from institutional theory and international business. Account. Forum 2018, 42, 65-77. [CrossRef]

41. DiMaggio, P.J.; Powell, W.W. The iron cage revisited: Institutional isomorphism and collective rationality in organizational fields. Am. Sociol. Rev. 1983, 48, 147-160. [CrossRef]

42. Miles, J.A. Management and Organization Theory; John Wiley \& Sons, Inc.: San Francisco, CA, USA, 2012.

43. Pishdad, A.; Haider, A.; Koronios, A. Technology and organizational evolution: An institutionalisation perspective. J. Innov. Bus. Best Pract. 2012, 1-12. [CrossRef]

44. Beach, L.R.; Mitchell, T.R. Part one: An introduction to Image Theory. In Image Theory: Theoretical and Empirical Foundations; Ebook; Routledge: Abingdon-on-Thames, UK, 1998; pp. 9-20.

45. Jayawardhena, C.; Morrell, K.; Stride, C. Ethical consumption behaviours in supermarket shoppers: Determinants and marketing implications. J. Purch. Supply Manag. 2016, 32, 777-805. [CrossRef]

46. Thomas, D.R. A general inductive approach for analyzing qualitative evaluation data. Am. J. Eval. 2006, 27, 237-246. [CrossRef]

47. Krippendorff, K. Content analysis: An Introduction to Its Methodology, 2nd ed.; Sage Publications, Inc.: Thousand Oaks, CA, USA, 2004.

48. World Business Council for Sustainable Development and World Resources Institute (WBCSD \& WRI). Greenhouse Gas Protocol Corporate Value Chain (Scope 3) Accounting and Reporting Standard. 2011. Available online: https:/ / ghgprotocol.org/standards/scope-3-standard (accessed on 22 October 2018).

49. World Business Council for Sustainable Development and World Resources Institute (WBCSD \& WRI). Supplier Engagement Guidance. 2011. Available online: http://www.ghgprotocol.org/standards/scope-3standard (accessed on 22 October 2018).

50. World Business Council for Sustainable Development and World Resources Institute (WBCSD \& WRI). Emission Factors from Cross-Sector Tools. 2017. Available online: http://www.ghgprotocol.org/ calculationtools (accessed on 22 October 2018).

51. Government of Canada. Canadian National Inventory Submission to the United Nations Framework Convention on Climate Change in National Inventory Submissions. 2017. Available online: http:/ / unfccc.int/ national_reports/annex_i_ghg_inventories/national_inventories_submissions/items/10116.php (accessed on 22 October 2018).

52. Cook, C.; Inayatullah, S.; Burgman, M.; Sutherland, W.; Wintle, B. Strategic foresight: How planning for the unpredictable can improve environmental decision-making. Trends Ecol. Evol. 2014, 29, 531-541. [CrossRef] [PubMed]

53. International Panel on Climate Change (IPCC). Climate Change 2014: Synthesis Report; Contribution of Working Groups I, II and III to the Fifth Assessment Report of the Intergovernmental Panel on Climate Change; Pachauri, R.K., Meyer, L.A., Eds.; IPCC: Geneva, Switzerland, 2014; Available online: http:/ /www. ipcc.ch/report/ar5/syr/ (accessed on 22 October 2018).

54. Schoemaker, P. Scenario planning: A tool for strategic thinking. Sloan Manag. Rev. 1995, 36, $25-40$.

55. Beer Canada. Industry Trends. 2017. Available online: http://industry.beercanada.com/statistics (accessed on 22 October 2018).

56. Damelio, R. The Basics of Process Mapping, 2nd ed.; Productivity Press: New York, NY, USA, 2011.

57. Patterson, R.E.; Pierce, B.J.; Bell, H.H.; Klein, G. Implicit learning, tacit knowledge, expertise development, and naturalistic decision making. J. Cogn. Eng. Decis. Mak. 2010, 4, 289-303. [CrossRef]

58. Sloane, T.R. Green beer: Incentivizing sustainability in California's brewing industry. Gold. Gate Univ. Environ. Law J. 2012, 5, 481-508. 
59. Barzagli, F.; Giorgi, C.; Mani, F.; Peruzzini, $\mathrm{M} . \mathrm{CO}_{2}$ capture by aqueous $\mathrm{Na}_{2} \mathrm{CO}_{3}$ integrated with high-quality $\mathrm{CaCO} 3$ formation and pure $\mathrm{CO}_{2}$ release at room conditions. J. CO2 Util. 2017, 22, 346-354. [CrossRef]

60. Marchi, M.; Neri, E.; Pulselli, F.; Bastianoni, S. $\mathrm{CO}_{2}$ recovery from wine production: Possible implications on the carbon balance at territorial level. J. $\mathrm{CO}_{2}$ Util. 2018, 28, 137-144. [CrossRef] 